\title{
Decisão e coisa julgada
}

\section{Enrico Tullio Liebman}

\section{I - Classificação das decisões do juiz}

O assunto que hoje vamos considerar com certo desenvolvimento é o da classificação das decisões.

A doutrina antiga e tradicional classificava as decisões em duas categorias: definitivas e interlocutórias.

A palavra interlocutória vem do latim "inter" e "locutus" e quer dizer "falar entre", "falar na fase intermédia". Sentenças interlocutórias são todas aquelas que o juiz profere, decidindo incidentes que se apresentam no curso do processo.

Por sua vez, a sentença interlocutória deve ser distinguida em duas categorias: mixta e simples. Sentença interlocutória simples é aquela que corresponde exatamente à definição de sentença interlocutória, isto é, aquela que decide alguma questão que se apresenta no curso do processo. Mas há casos em que o juiz ao decidir um incidente prejudica de algum modo o processo em si mesmo; neste caso, chama-se esta sentença de interlocutória mixta ou interlocutória com força de definitiva. Exemplo: quando o juiz, examinando a legitimidade das partes verifica que uma delas é ilegítima e, portanto, o processo não pode continuar, pronuncia, uma decisão que encerra o processo. Mas apesar disso a controvérsia permanece imprejudicada. Não se

(*) Notas taquigraficas das aulas proferidas na Faculdade de Direito de São Paulo, no ano de 1944. 
pode chamar tal sentença de definitiva, porque não decide o mérito da causa. Tão pouco se poderá dizer que se trata de uma sentença interlocutória no sentido restrito, isto é, sentença proferida na fase intermédia do processo. Dai o chamar-se sentença interlocutória com valor de definitiva, ou sentença interlocutória mixta.

Esta classificação das sentenças está bem longe de corresponder à idéia dos romanos em matéria de processo. Sentença era só a decisão final da causa. "Sententia" era o ato que decidia a controvérsia, condenando ou absolvendo o réu. A todos os decretos que o juiz proferia para ordenar a marcha do processo, chamavam os romanos de "interlocutiones", e não tinham nem a forma, nem a eficácia da "sententia", podendo a qualquer tempo ser modificadas, e até na segunda instância.

Foi no direito intermédio que o conceito de sentença se extendeu, passando a compreender todas as decisões do juiz. $\mathrm{E}$ as que os romanos chamavam de interlocutiones chamaram-se sentenças interlocutórias, com consequências práticas de grande relevo, como teremos oportunidade de vêr ao estudarmos os recursos.

A técnica do Código do Processo Civil vigente, porém, tal como a doutrina moderna, não acolheu essa classificação. A classificação moderna começa por distinguir as decisões finais das interlocutórias.

As decisões finais por sua vez se dividem em definitivas e terminativas do processo.

As interlocutórias dividem-se em: despachos interlocutórios e despachos de expediente ou ordenatórios.

Decisões finais são aquelas que fazem terminar o processo. Prolatada a decisão final, termina a instância, o juiz encerra a sua função e não mais pode modificar a situação jurídica, senão por força de novos acontecimentos, como seja, a interposição de recurso, etc. Mas a função que o juiz 
inicia, no momento em que recebe a petição inicial, finda ao pronunciar a decisão final. Essa decisão final pode ser de duas espécies: o juiz pode decidir a controvérsia no mérito, como também pode declarar não poder decidíla no mérito. Em ambos os casos o juiz põe fim ao processo. Num caso, porém, exercitando efetivamente a sua função de juiz, isto é, julgando a controvérsia; no outro caso, deixando a situação das partes, quanto à controvérsia, imprejudicada, por declarar não poder entrar no exame e no julgamento do mérito, por algum defeito do processo.

Já aprendemos a distinguir a relação jurídica processual da relação jurídica material ou substancial, que é o objeto do processo. O juiz não pode examinar a controvérsia e julgar si o processo não está de acordo com as regras do direito processual. Si o processo não apresentar aqueles requisitos mínimos, fundamentais, que a lei exige para o considerar regularmente instaurado, permitindo o exame da controvérsia proposta pelas partes, o juiz ao verificar que tal processo não apresenta esses requisitos, ou por defeito dos atos iniciais, ou por falta dos pressupostos processuais, ou ainda por alguma nulidade dos atos sucessivos do processo, nestes vários casos deve declarar o defeito, a irregularidade, a nulidade. Nestes casos todos o juiz não decide sobre a relação material controvertida e sim, unicamente, sobre a relação processual. A decisão que ele profere faz terminar o processo, deixando tal como $_{0}$ estava a controvérsia principal existente entre as partes. O Código de processo chama esta aecisão de terminativa do processo.

Ao contrário, si o juiz encontra o processo regularmente formado e instaurado, observadas todas as prescrições legais na execução dos vários atos processuais, pode entrar $n_{0}$ exame da controvérsia, estudar os pedidos das partes, examinar as provas apresentadas e enfim pronunciar-se sobre o pedido para declará-lo procedente ou improcedente. Neste 
caso temos a decisão definitiva. Só neste caso o processo alcançou a sua finalidade: a lei foi estabelecida entre as partes, cada uma delas sabe o que deve, o que pode fazer, a justiça foi aplicada. Esta é a sentença definitiva. A rigor só esta se chama sentença.

Restaurando a antiga terminologia latina, a doutrina moderna e o Código de processo manifestam a tendência de restringir o uso da palavra "sentença" unicamente para as decisões definitivas do mérito. As decisões finais simplesmente terminativas do processo não são realmente sentenças.

Vejamos agora as decisõs interlocutórias.

No decurso do processo o juiz tem várias vezes oportunidade de falar. Quando o juiz fala no processo sempre decide, ordena, decreta alguma coisa. Todos esses atos do juiz também são decisões, embora não sejam decisões finais. Rejeitando a velha terminologia de "sentenças interlocutórias", indicamos êsses vários decretos do juiz como "decisões interlocutórias".

Essas decisões dividem-se em: despachos interlocutórios e despachos de expediente. A lei no art. 20 do Código de processo fala dos prazos concedidos ao juiz para pronunciar esses despachos, distinguindo bem os despachos interlocutórios dos de expediente.

Art. 20 - "O prazo para os despachos de expediente será de vinte e quatro (24) horas, e para os interlocutórios, de cinco (5) dias,"

Pela diferença de prazos já se vê que um deles é mais importante, o outro mais simples. Com efeito, o despacho interlocutório é aquele no qual o juiz decide alguma questão incidente que se apresenta no curso do processo, o que faz logo, sem remetê-la para decisão final. Ao contrário, o despacho de expediente não decide uma questão controvertida entre as partes, apenas dispõe sobre a marcha do processo. Uma petição apresentada em cartório não será despachada, nem o réu citado senão por despacho do 
juiz. O réu apresenta sua contestação; essa contestação não é juntada aos autos sem um despacho do juiz, e assim por diante. Cada passo que dá o processo é marcado por um despacho do juiz, que ordena se faça tal coisa, se juntem tais documentos, se cite, se ouça esta parte, etc. Estes são os despachos de expediente, que nada decidem, apenas dispõem sobre o andamento do processo.

Quando, porém, para decidir uma questão qualquer surge uma controvérsia entre as partes (suponhamos que o réu afirme, em contraposição ao autor, que o juiz é incompetente, ou suponhamos que o réu conteste a legitimidade do autor, etc.); em todos estes casos o juiz decide uma questão, e o ato pelo qual decide é um despacho interlocutório ou decisão interlocutória, se o juiz decidir no sentido da continuação do processo.

Entre os despachos interlocutórios, há um que se destaca pela sua importância e que tem um nome especial, que evidencia a sua função específica: o despacho saneador. Ele tem a função de sanar o processo, isto é, limpá-lo de seus eventuais defeitos e livrá-1o das questões que possam existir quanto à sua regularidade, abrindo assim caminho para a instrução e o julgamento do mérito da ação.

0 art. 294 do Código de processo indica as questões que devem ser decididas neste despacho. Se a decisão é negativa, porque declara subsistente um destes defeitos, o juiz profere uma decisão terminativa, que põe fim ao processo sem lhe resolver o mérito. Se a decisão é positiva e declara regularmente instaurado o processo, providenciando para a instrução da causa, temos o verdadeiro despacho saneador em sentido estrito, que é um despacho interlocutório.

O saneamento do processo pode também ocorrer em duas etapas. Com efeito, ao examinar as questões indicadas no art. 294, o juiz pode encontrar irregularidades ou nulidades sanaveis. Neste caso a lei não quer que o juiz anule o processo. Para economisar tempo e dinheiro e aproveitar quanto possível a atividade processual já realizada, 
deve o juiz mandar suprir essas nulidades e irregularidades. Realizadas as necessárias diligências, o juiz proferirá um novo despacho para constatar o cumprimento de suas disposições e designar a audiência de instrução e julgamento. Será este tambem um despacho saneador, que completa o primeiro.

Esquematizando a classificação moderna das decisões, temos:

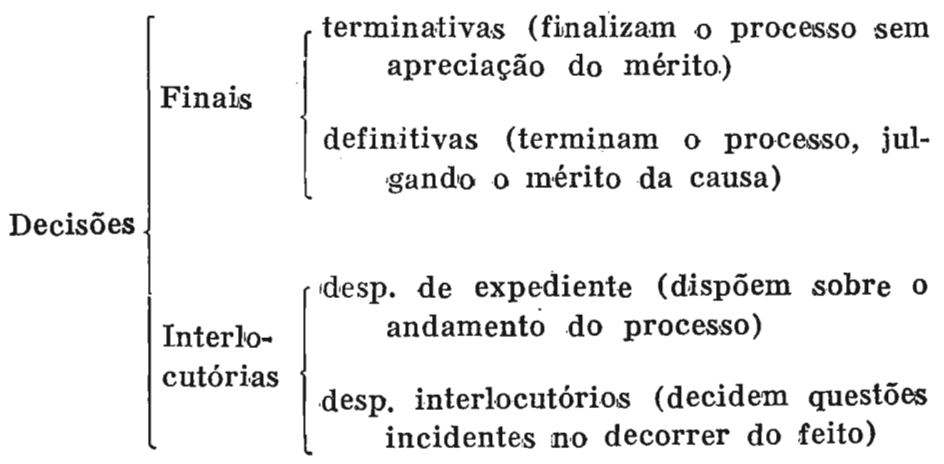

\section{II — Efeitos das decisões interlocutórias}

Segundo uma regra tradicional, que se encontra nas Ordenações Portuguesas, quando o juiz profere uma decisão final, ele exgota seu poder e sua função no processo, o que (com palavras das fontes romanas) se exprimia dizen." do que ele "functus est officio suo". De acordo com esta regra, acontece o contrário, quando o juiz profere uma decisão interlocutória.

Portanto, proferida a decisão final, cessa para o juiz a possibilidade de intervir de qualquer forma no processo que ele próprio encerrou, a não ser que atos sucessivos venham abrir uma nova fase do processo, como seria a interposição de um recurso ou o pedido de execução da sen- 
tença; em especial, não pode o juiz modificar a sua decisão. Ao contrário, quando o juiz profere as decisões interlocutórias, não exgota seu poder no processo, porque, justamente por ser a decisão interlocutória, o processo deve continuar e ao próprio juiz cabem os poderes necessários para acompanhar e fazer o processo marchar para a frente. Em consequência disso, ele pode sempre considerar novamente as questões decididas no despacho interlocutório e, eventualmente, modificar ou revogar esta decisão.

Esta regra, formulada de um modo um tanto vago, dava lugar a alguns inconvenientes, complicações e demoras; com efeito, nunca há segurança de que um passo dado para a frente seja definitivo, se em qualquer momento o juiz pode voltar para traz e dar ao processo novo rumo. Em nosso tempo é muito maior a aspiração a que o processo tenha um andamento rápido e preciso. Por conseguinte, a possibilidade da modificação das decisões interlocutórias sofre importantes restrições.

Acontece, com ef eito, que algumas destas decisões podem ser recorridas, segundo regras que serão estudadas em seu devido tempo; para outras, ao contrário, a lei não prevê nenhum recurso possivel.

Ora, quando a lei estabelece a possibilidade de a parte interessada recorrer duma decisão, reconhece com isso à própria parte um direito subjetivo processual de obler o reexame da questão decidida, direito que deve ser exercido em formas e prazos determinados. E' evidente, pois, a conclusão de que nestes casos tal efeito só pode ser atingido com o exercício, nas formas devidas, desse direito da parte, isto é, com a interposição do recurso; sem a interposição do recurso, a decisão não pode ser modificada.

Chegamos assim ao resultado seguinte: quando uma decisão interlocutória pode ser recorrida, sua modificação só pode ocorrer, em consequência, nas formas e com os efeitos da interposição do recurso; ao contrário, quando a lei 
não estabelece a possibilidade de um recurso, a decisão pode ser modificada sem formalidade alguma pelo próprio juiz que a proferiu, a requerimento da parte, ou "ex offjcio". Contudo, também nestes casos a modificação não poderá ocorrer em qualquer tempo; ela só será possível enquanto o andamento da causa ainda o permitir, isto é, se o processo não atingiu ainda em sua marcha para frente um ponto tal que a questão decidida deva ser considerada como superada.

Resumindo, uma decisão não poderá ser modificada pelo juiz nos casos seguintes:

a) se recorrível, e o recurso não foi interposto;

b) se recorrida, foi confirmada pela instância superior;

c) se embora não recorrivel, o processo, tendo continuado a sua marcha, atingiu uma situação que seria incompatível com a modificação da decisão.

Nos outros casos o juiz pode revogar ou modificar a sua decisão.

Quando, verificando-se os casos indicados, a decisão interlocutória se tornou imutável, temos uma "preclusão". Chama-se preclusão a perda de uma faculdade ou de um direito subjetivo processual, perda que pode ocorrer porque não se fez uso dessa faculdade no momento e no prazo devido, ou porque se realizaram atos incompativeis com a vontade de usar dessa faculdade ou ainda, porque já se fez uso dela uma vez (consumação).

As preclusões são frequentes no processo, como expediente de que se serve a lei para dar ordem, precisão e rapidez ao processo. Uma de suas aplicações mais importantes é justamente esta de que estamos falando, e que consiste em tornar definitivo, imutável o efeito produzido pelas decisões interlocutórias e afastar desse modo, à medida em que se apresentam e são decididas, as muitas questões processuais que podem ser suscitadas no decorrer do 
processo. Por exemplo: proferido o despacho saneador, se a parte interessada não interpõe o recurso cabível (agravo no auto do processo, art. 851, n. IV do Cód. de Proc. Civil), as questões decididas no despacho não mais poderão ser suscitadas no decorrer do mesmo processo.

Seria inexato falar de coisa julgada a respeito desse efeito da preclusão. A coisa julgada, como veremos melhor nas próximas aulas, só tem lugar nas decisões que resolvem o mérito do processo, ou seja, de acordo com nossa classificação, nas decisões definitivas (sentenças) (art. 287, 288 do Cód. Proc. Civil). Seu efeito está destinado a repercutir em qualquer novo processo em que o mesmo assunto possa ser objeto de discussão. Ao contrário, a preclusão produzida por uma decisão interlocutória só vale para o próprio processo em que se produziu, pois, só é nele que podem ter relevância as questões processuais decididas.

Esse efeito da preclusão não se produz unicamente quando o juiz decide de modo explícito uma questão. Temos até casos em que a preclusão se produz por decisão implícita do juiz, e isso acontece, quando o despacho interlocutório tem, de acordo com a lei, uma função específica, que não pode ser realizada sem decidir previamente alguma questão. Nesse caso, a prolação de um despacho desse tipo implica necessariamente na decisão destas questões prévias.

O exemplo mais evidente é ainda o do despacho saneador. A função saneadora desse despacho consiste necessariamente na decisão das questões duvidosas acerca da regularidade da instauração do processo. Sanear o processo, quer dizer justamente limpá-lo de dúvidas. $O$ art. 294 do Código indica as questões que o juiz deve decidir ao proferir o despacho saneador. Ora, acontece muitas vezes que o juiz não decide expressamente no despacho saneador algumas das questões indicadas no art. 294. Declara saneado o processo, deixando de fazer menção especial à questão da legitimidade das partes, ou à questão da 
regularidade dos atos processuais até aquele momento realizados. Podemos perguntar: nesse caso, essas questões não expressamente decididas, mas que são necessariamente questões prévias no saneamento do processo, devem ou não ser consideradas como decididas implicitamente si o despacho não é recorrido, a preclusão abrangerá também essas questões não expressamente decididas, mas que deviam ser para poder ser proferido o despacho saneador?

A resposta é afirmativa. Essa decisão implícita das questões que se deviam considerar como necessariamente prévias ao efeito que o despacho é destinado a produzir, tem a consequência de fazer com que a preclusão abranja todas essas questões. Por exemplo: o juiz no despacho saneador declara saneado o processo, mas esquece de indicar que decidiu também sobre a legitimidade das partes; apesar disso, si não há recurso, a questão da legitimidade está resolvida.

No caso do despacho saneador essa conclusão é fácil, porque a lei expressamente indica os assuntos sobre os quais deve versar; portanto, proferido o despacho saneador, necessariamente estarão decididas essas questões, no sentido de que o processo está regularmente instaurado. Em outros casos, porém, em que a lei não é expressa e não indica taxativamente ao juiz as questões que deve decidir, será um pouco mais difícil indicar exatamente o alcance da preclusão. Mas ainda nestes casos, devemos dizer que todas as questões necessariamente prévias ao efeito que o despacho está destinado a produzir se devem considerar como implicitamente decididas; e si não fôr interposto recurso, compreendem-se no efeito da preclusã̃o.

$\mathrm{E}^{\prime}$ isto que se pode dizer sobre as decisões interlocutórias, e sobre o modo e a espécie de efeitos que elas produzem.

Nas próximas aulas veremos qual a eficácia e os efeitos das decisões finais, e principalmente da decisão definitiva. 


\section{III — Efeitos das decisões terminativas}

Continuemos a examinar as várias decisões no que se refere aos seus efeitos. E' o momento de tratarmos das decisões terminativas do processo.

Qual será o efeito das decisões terminativas?

Seu nome, sua definição já respondem: encerram o processo sem julgar o mérito. Estas decisões estão sujeitas a recurso especial, que se chama agravo de petiçăo. Si, decorrido o prazo para recurso, ele, entretanto, não é interposto, a decisão se torna definitiva, imutável, e o efeito do encerramento do processo também se torna definitivo e imutável.

Será que esse resultado se pode qualificar como "coisa julgada"? Este é um problema que examinaremos melhor mais tarde. Por ora, a respeito das decisões terminativas nada mais nos resta dizer.

\section{IV - Sentença. Seu conteúdo}

Passando ao estudo das decisões definitivas, da sentença, ato final e culminante do processo, e para cuja prolalação contribuem todas ás atividades desenvolvidas no processo, diremos que o processo não é senão uma preparação desse ato com o qual o juiz finalmente recolhe os vários elementos conseguidos no decorrer do feito, examina as provas, as opiniões e razões jurídicas desenvolvidas pelas partes e profere a sua decisão. E' nesse ato que o Estado exerce propriamente a sua função jurisdicional.

Podemos definir a sentença como o ato pelo qual o juiz decide a lide, isto é, julga a causa declarando procedente ou improcedente a ação proposta.

Nessa definição usei pela primeira vez da palavra "lide", palavra que tem na linguagem jurídica mais de uma 
significação. Devemos, porém, atribuir-lhe um sentido técnico, porque a lei no art. 287 a emprega com esse significado técnico.

Art. 287 - "A sentença que decidir total ou parcialmente a lide terá força de lei nos limites das questões decididas." lide?

Que quererá dizer "lide" e decisão total ou parcial da

Essa palavra "lide" vem do latim, "lis,litis" e significa demanda, litígio. O código usa da expressão "lide" para referir-se ao mérito da causa. Querendo dar uma definição um pouco mais precisa desse conceito fundamental, porque indica o objeto do processo, poderiamos dizer que "lide" é o conflito entre os pedidos contrários das partes. Conflito que o juiz pode resolver, decidindo pela procedência ou improcedência do pedido do autor.

Neste ponto poderá surgir esta objeção à definição: Pode acontecer que o réu seja revel, ou embora presente não faça nenhum pedido, ou ainda, embora fazendo pedido, concorde com o pedido do autor e, portanto, em todos esses casos não haverá conflito de pedidos. Haverá só o pedido do autor, ou haverá pedidos coincidentes do autor e do réu.

Penso que a objeção não procede pelas razões seguintes: o juiz deve decidir sobre o pedido do autor, qualquer que seja a atitude do réu no processo. A atitude do réu no processo pode facilitar ou dificultar o trabalho do juiz, mas não tem importância decisiva sobre o resultado final, sobre a decisão do juiz.

$\mathrm{O}$ fato de o réu concordar com o autor, quanto ao pedido, não modifica de nenhum modo a obrigação do juiz de examinar si esse pedido é realmente procedente ou nào. 0 acordo do réu com o autor de forma alguma exime o juiz de verificar si o pedido do autor é realmente procedente. Assim é, pela razão de que o juiz não deve provi- 
denciar sobre o pedido de uma parte, senão quando se convencer de que esse pedido efetivamente procede. A atitude da outra parte não pode eximir o juiz da sua obrigaçso de verificar a procedência do pedido, poderá quando muito influir sobre as atividades instrutórias. Portanto, qualquer que seja a atitude do réu, deve o juiz examinar si o pedido do autor é procedente ou não, tal como aconteceria si o réu contestasse o pedido do autor e formulasse um pedido contraditório.

Chegamos, portanto, à conclusão de que o objeto do processo é sempre o conflito efetivo ou virtual dos pedidos formulados pelas partes. Que seja efetivo ou virtual não tem importância deste ponto de vista, terá muita importância, quando tratarmos da estrutura do processo, assunto que por ora não nos preocupa.

Qualquer que seja a atitude do réu em face do pedido que o autor formulou e que deve ser examinado em sua procedência, tanto si o réu concorda com ele, quanto si o contesta (o que acontece na maioria dos casos), formulando um pedido contrário, a decisão do juiz é afinal a resposta que ele dá ao pedido do autor.

Esquematizada ao máximo a estrutura do processo, ele se nos revela como a atividade desenvolvida pelo juiz para responder a um pedido que o autor lhe fez afim de que profira determinada providência. 0 juiz deve decidir si essa providência deve ou não ser concedida. A sua decisão consiste, justamente, nesse julgamento que ele faz sobre o pedido, deferindo ou não a providência que o autor lhe pede.

Portanto, o juiz deve unicamente decidir sobre os pedidos das partes. Não pode decidir sobre assuntos que não sejam compreendidos no pedido das partes.

ART. $4 .^{\circ}$ - "O juiz não poderá pronunciar-se sobre o que não constitua objeto do pedido, nem..." 
Si o juiz julga sobre assuntos que não constituem objeto do pedido incorre naquele vício da sua decisão que se chama "extra petita" ou "ultra petita", quer dizer, julgar fóra, ou além do que foi pedido.

Qual será o critério para saber si o juiz ficou exatamente no limite dos pedidos, si julgou exatamente para declarar a procedência ou improcedência do pedido formulado? Qual o meio para se saber si a petição inicial e a decisão coincidem?

Pela identidade de seus elementos. Assim como os indivíduos são identificados pela côr dos olhos, do cabelo, dã pele, etc., do mesmo modo a ação, a lide, o pedido têm elementos que servem para os identificar. São eles: as partes, o objeto e a causa.

Quando a ação proposta e a ação julgada têm os mesmos elementos identificadores, isto é, as mesmas partes, referindo-se ao mesmo objeto e tendo a mesma "causa petendi", então diremos que o juiz julgou exatamente a ação proposta, e que permaneceu dentro dos seus poderes. Por outro lado, si ele julgou com referência a outra pessoa, ou outro objeto, ou outra "causa petendi" das que constituiam os elementos da ação proposta, ele julgou "extra petita" ou "ultra petita" e a decisão é viciada. Não nos vamos deter aquí para estudar que expécie de vicio é este. Sabemos que é uma decisão viciada, e isto é o que interessa no momento.

O conteúdo da sentença é, portanto, a decisão da lide. Mas como o juiz decide esta lide? Qual o caminho lógico que o juiz deve percorrer para decidir a lide?

Deve examinar si os fatos afirmados pelas partes como existentes resultam provados, e si as consequências jurídicas desses fatos são aquelas que as partes pretendem. Portanto, seu trabalho lógico se divide em duas questões fundamentais: uma questão de fato e uma questão de direito.

A questão de fato nada mais é do que a reconstrução histórica dos fatos da lide, Por exemplo: O autor afirma 
que foi atropelado por um auto na esquina da rua Senador Feijó, e que isso aconteceu, porque o carro não seguia a mão direita. Deste fato podem resultar consequências jurídicas muito sérias. $\mathrm{O}$ juiz deve em primeiro lugar verificar si os fatos foram justamente esses: si, de fato, o auto n. ${ }^{\circ}$......, passando à contra-mão pela esquina da rua Senador Feijó, às .... horas do dia ...., atropelou Fulano de tal (autor); deve recolher os depoimentos das testemunhas, e com todos estes elementos formará uma opinião. E' o trabalho de reconstrução histórica dos fatos, que são examinados em todos os seus pormenores.

Confirmada a veracidade dos fatos, começa a segunda parte do trabalho do juiz, que é a questão de direito, isto é, estabelecer de acordo com todas as leis vigentes qual a consequência jurídica decorrente desses fatos. Esse trabalho, que se refere à questão de direito, implica evidentemente na interpretação exata das leis e na exata aplicação do princípio jurídico estabelecido pelas leis aos fatos que em concreto se verificaram. Todo esse trabalho lógico do juiz forma, em última instância, um silogismo.

Que é silogismo? E' uma figura lógica fundamental para o raciocínio, e consiste em estabelecer duas premissas, uma maior e outra menor, e delas tirar uma conclusão. 0 exemplo mais conhecido é o seguinte:

Todos os homens são mortais.

Ora, Fulano é homem.

Logo, Fulano é mortal.

Outro exemplo, de aplicação geograficamente um pouco mais restrita, seria o seguinte:

(Pr. maior) - Nas grandes cidades o tráfego se torna difícil.

(Pr. menor) - São Paulo é uma grande cidade.

(Conclusão) - Aquí em São Paulo o tráfego urbano ẻ assunto difícil. 
Pois bem, o juiz fará exatamente isso. 0 autor diz qua é proprietário de um imóvel, que o réu possue sem direito, e pede então a entrega desse imóvel. O juiz examina os fatos, verifica que as afirmações do autor são verdadeiras, e condena o réu a entregar a coisa reivindicada. Qual o caminho lógico desse raciocínio?

A lei estabelece o seguinte:

(pr. maior) - Quem possue uma coisa que não lhe pertence deve entregá-la ao legítimo proprietário.

(pr. menor) - Fulano, autor, é o legítimo proprietário do imóvel que o réu detém.

(conclusão) - O réu é condenado a devolver a coisa que possue a Fulano, seu legítimo proprietário.

A premissa maior contém uma regra de direito de caráter geral. A premissa menor contém uma definição da situação jurídica do caso concreto. A conclusão é a aplicação da premissa maior, isto é, da regra jurídica à premissa menor, isto é, ao caso concreto, e as consequências que dessa aplicação decorrem.

Nem sempre o caso se apresenta tão simples, a ponto de resultar a decisão de um único silogismo. Muitas vezes a decisão se decompõe em vários silogismos, em silogismos sucessivos, mas em última instância, por assim dizer, sempre o raciocínio do juiz se reduz a um silogismo como o que estudamos.

O processo contém, além da lide principal, uma lide accessória que se refere às custas do processo. $O$ art. $283 \mathrm{diz}$ :

ArT. 283 - "A sentença decidirá quanto ao onus das custas, ainda que não conste da petição inicial o pedido de pagamento."

A sentença, além de decidir a lide de que falámos até agora, deve decidir uma lide por assim dizer accessória, 
que é constituida pelo probléma do onus das custas do processo, para atribuir este onus a uma ou a outra parte, ou eventualmente a ambas, de acordo com princípios que vamos estudar oportunamente. Essa lide accessória escapa à regra de que o juiz pode só decidir sobre pedidos das partes. Essa é por assim dizer uma lide necessária. A lei expressamente declara que o juiz deve decidir sobre esse assunto, independentemente de existir ou não pedido das partes a respeito da condenação nas custas.

Os arts. 59 e seguintes do Código de Processo estabelecem as regras gerais sobre o onus das custas, assunto que será desenvolvido na parte final do nosso curso.

Estudado o conteúdo da decisão do juiz, passemos agora a vêr qual a forma dessa decisão.

As disposições expressas do art. 280 do Código reproduzem materialmente os vários elementos de que se compõe a decisão.

Art. 280 - “A sentença, que deverá ser clara e precisa, conterá :

I. O relatório.

II. Os fundamentos de fato e de direito.

III. A decisão.

Parágrafo único - $\mathrm{O}$ relatório mencionará o nome das partes, o pedido, a defesa e o resumo dos respectivos fundamentos."

O relatório da decisão, mencionando o nome das partes, o pedido, a defesa e o resumo dos respectivos fundamentos, indica alguma coisa muito importante, isto é, identifica a ação.

Natureza da sentença

Para definir a natureza jurídica da sentença devemos esclarecer se ela é um ato da inteligência ou da vontade do juiz. 
Afirma uma corrente da doutrina que o juiz só deve examinar as circunstâncias da caụsa e verificar se elas integram a hipótese prevista pela lei em suas disposições. Desse exame resultaria se se aplica ao caso concreto a regra legal abstrata. Com essa constatação term:naria a tarefa do juiz. A sua atividade seria, portanto, simplesmente lógica e redundaria num puro ato intelectual.

Não há dúvida que o juiz deve fazer esse trabalho de pesquiza da verdade e de investigação da regra de direito que se aplica ao caso e que, assim, uma grande parte de sua atividade no processo tem natureza puramente lógica. Contudo, parece mais exata a opinião daqueles que sustentam que a sentença representa ao mesmo tempo um ato da inteligência e também da vontade do juiz: é um ato da inteligência que se conclue com um ato da vontade. Com efeito, o juiz não se limita a verificar quais consequências decorrem de acordo com a lei dos fatos que se provaram no processo como verdadeiros; depois de conseguido esse resultado, ele julga, decide a controvérsia, isto é, ordena, determina que tenham lugar essas consequências. A sentença tem assim o efeito de um imperativo, de um comando que deve ser obedecido e cumprido, e é justamente isto que se quer dizer ao falar de um "ato de vontade."

$E^{\prime}$ verdade que a lei já contém um imperativo e que o juiz nada pode dispor que não esteja de acordo com a lei. Mas o imperativo legal é abstrato e geral, ao passo que o imperativo contido na sentença é concreto e especial e se refere diretamente ao caso decidido. A função do juiz. consiste propriamente nesta especialização da regra legal abstrata, na formulação do preceito concreto que resolve a controvérsia submetida a seu julgamento.

Isto não quer dizer, porém, que o juiz venha a criar com sua sentença o direito para o caso concreto. A função do juiz, em regra, é declarativa, não constitutiva. Ele verifica, constata, declara a existência de uma relação de di- 
reito pre-existente. $O$ processo é feito para realizar o direito, não para modificá-lo. Por exemplo: quando o juiz. condena o devedor a devolver a importância devida, não se deve crer que é da sentença que nasce a obrigação do devedor. Esta existia também antes, pois se originou do fato constitutivo da relação obrigacional, isto é, conforme o caso, do mútuo, ou do ato ilícito, e assim por diante. A sentença ao declará-la nada lhe acrescenta a não ser a certeza de sua existência, e eventualmente (quando é condenatória) a possibilidade de ser realizada coativamente por meio da execução. Importa observar neste ponto que o caráter declarativo do efe to produzido pela sentença não está em contradição com a sua força imperativa que há pouco lhe reconhecemos. Na verdade, o juiz repete em forma concreta, para o caso controverso, o imperativo abstrato já existente na lei e que por motivos vários não tinha recebido obediência pelas partes. Já sabemos, por outro lado, que existe uma categoria de sentenças que não são meramente declarativas e que por isto mesmo recebem o nome de constitutivas. Por exemplo, quando o juiz anula um contrato viciado por êrro, além dé constatar a existência da relação contratual e a existência do êrro, tira destas circunstâncias as consequências legais, anulando o contrato e modif:cando assim (como veremos melhor mais adiante) a situação jurídica existente. Mas estes casos são pouco numerosos e em regra a natureza da sentença é meramente declarativa.

Vamos estudar por último si a atividade do juiz é juridicamente vinculada, ou discricionária.

Na grande maioria dos casos a lei prevê exatamente quais devem ser as consequências dos fatos previstos na norma. Si os faíos se verificam o juiz sabe exatamente o que deve prescrever como consequência. Mas ha alguns casos em que a lei não prevê exatamente as consequências dos fatos, ou a medida exata dessas consequências. 
Na sociedade dominada pelos princípios da doutrina liberal quasi que não havia esses casos de poder discricionário, porque de acordo com essa doutrina as relações entre as pessoas deviam estar exatamente disciplinadas pelas leis, de forma abstrata e geral, e o juiz outra coisa não devia fazer senão aplicar essas leis. Mas hoje em dia estamos vivendo uma época em que cada vez mais nos afastamos dessa sociedade disciplinada pela doutrina liberal. Em todo o mundo vai crescendo a intervenção dos poderes públicos na regulamentação das relações da vida social, exíge-se a intervenção do poder público em casos que é impossível à lei prever a forma exata dessas relações. Daí a necessidade de a lei atribuir ao juiz o poder de intervir nessas relações, dando-lhes a regulamentação conveniente.

Num mundo liberal seria impossivel pensar-se num juiz que pretendesse estabelecer qual seja, num caso concreto, o justo preço de uma mercadoria, ou de uma atividade pessoal, por exemplo, o salário justo, porque tanto o preço quanto o salário, de acordo com as regras da economia liberal são fixados pelo livre jogo da procura e da oferta, e nada poderia o juiz fazer para estabelecer este preço ou este salário justo. Mas cada dia mais em todo o mundo se exige do poder público essa intervenção nas relações individuais e coletivas, com o intento de dar a essas relações um conteúdo mais justo, não simplesmente aquele resuliante do livre jogo das forças econômicas, mas sim para dar a essas relações um conteúdo mais rico em defesa, por ex., ao mais fraco, economicamente, dos contratantes, como é em geral o trabalhador em face do empregador.

Portanto, surgindo esses vários conceitos, do justo salário, do justo preço, conceitos que o legislador não pode prever e estabelecer em abstrato nas suas normas, passouse a atribuir ao juiz o poder de fixar, caso por caso, de acordo com as circunstâncias, em cada caso diferentes, qual 
a medida a ser estabelecida, qual o conteúdo a ser dado a certas relações. Nestes casos, que ainda são poucos, mas que já aparecem com mais frequência que antigamente, o juiz recebe um poder discricionário, que ele exerce ao decidir a controvérsia e ao dar a sua decisão conteúdo que não se pode dizer seja a simples aplicação da regra dada pelas leis. $\mathrm{O}$ caso mais importante de poder discricionário do juiz, previsto no Código Civil, é o caso dos alimentos.

ArT. 400 - "Os alimentos devem ser fixados na proporção das necessidades do reclamante e dos recursos da pessoa obrigada."

$\mathrm{E}^{\prime}$ evidente que nenhuma lei poderia prever em abstrato, em geral, qual a medida justa dos alimentos a ser prestados por alguem a favor de outrem. E' preciso considerar quais os recursos do obrigado, quais as necessidades daquele que recebe os alimentos. Não há outra solução possível senão esta de atribuir ao juiz o poder de examinar os elementos em cada caso determinado e conceder o que lhe parecer justo.

Mas este poder do juiz nos casos de atividade discricionária será arbitrário? Poderá o juiz fixar essa medida sem limites?

Evidentemente, não. Nesses casos ele nada mais é do que o intérprete da conciência geral do povo, da conciência social. Há regras jurídicas que receberam a forma de lei positiva e que se encontram em leis nos códigos. Existe, na generalidade da gente que vive num país, num tempo determinado, um conjunto de opinióes e critérios sobre o justo e o injusto, que o juiz nestes casos de atividade discricionária deve buscar e aplicar. $E^{\prime}$ isto que quer dizer o artigo 114 do Código de Processo, quando preceitua: 
ArT. 114 - "Quando autorizado a decidir por equidade, o juiz aplicará o norma que estabeleceria se fosse legislador."

Este artigo deveria lembrar aos srs. uma disposição muito conhecida de um direito estrangeiro. E o art. $10^{\circ}$ do Códigq Suisso das Obrigações, que estabelece que nos casos de lacuna da lei, o juiz deve decidir como si fosse leg.slador. Este critério é o mesmo do artigo 114 do código brasileiro, mas os casos em que se recorre a esse critério são diferentes na lei suissa e na lei brasileira.

A lei suissa atribue esse poder ao juiz sempre que haja lacunas, sempre que a lei não tenha disposição expressa sobre o caso, o que na verdade é bastante frequente, porque os códigos, por grandes que sejam, por muitas disposições que contenham, nunca podem prever todas as hipóteses que se apresentam na vida.

De acordo com a lei brasileira, não havendo dispositivo legal, temos a analogia e os princípios gerais do direito. 0 juiz brasileiro deve, em primeiro lugar, vêr si há disposição expressa; se não existe, deve recorrer à analogia; e sendo esta insuficiente, recorrer aos principios gerais do direito, o que ainda vincula o juiz ao sistema legislativo do país.

Como se vê, o juiz suisso é mais livre e independente do direito escrito do que o juiz brasileiro. Esse poder quasi legislativo do juiz se admite no Brasil unicamente nos casos em que a própria lei lhe atribue o poder de decidir por equidade, isto é, com atividade discricionária.

Neste ponto surge uma questão teórica bastante interessante. Si o juiz decide o caso como o decidiria si fosse legislador, num "espaço vasio de direito", isto é, quando não há regras a aplicar o juiz parece exercitar mais uma atividade legislativa que propriamente jurisdicional. Si em regra o Poder Judiciário tem uma função de aplicar as regras gerais contidas nas leis aos casos concretos, quando a regra 
geral não existe e ele é chamado a formular como regra nova e individual a regra para o caso concreto, há uma corrente da doutrina que sustenta que neste caso a sentença, embora emitida pelo Poder Judiciário, nas formas dos atos judiciários, na verdade, e em substância se apresenta como um ato legislativo.

Penso, porém, que tal afirmação não está certa, porque o caráter necessário e típico da atividade legislativa é a sua generalidade, a sua abstração. São regras de conteúdo legislativo aquelas que se apresentam como abstratas e gerais. Quando uma regra não é geral e abstrata e se refere a um caso concreto e específico, já não é uma regra legislativa. Tanto isto é verdade que, nos casos, sem dúvida excepcionais, mas existentes, em que o Poder Legislativo profere atos de conteúdo individual e concreto, a técnica do direito constitucional chama esses atos de "leis formais", isto é, são atos que têm a forma de lei, mas não a substância de lei, justamente, porque são concretos e individuais. Portanto, isso confirma o caráter necessariamente abstrato e geral dos atos legislativos.

Quando o juiz decide de acordo com a equidade, aplicando o artigo 114 do Código de Processo, estabelecendo a regra para o caso concreto, que não tem eficácia para outro caso senão esse, esse ato não é legislativo, mas simplesmente judiciário como todos os atos do juiz.

\section{Requisitos formais da sentença}

A sentença deve em primeiro lugar identificar a lide que vai ser decidida. Deve em segundo lugar dar conta do trabalho lógico feito pelo juiz para examinar a causa. Deve em terceiro lugar conter a decisão. Temos assim as três partes de que se compõe a sentença como ato escrito. 
ART. 280 - “A sentença, que deverá ser clara e precisa, conterá :

I. O relatório.

II. Os fundamentos de fato e de direito.

III. A decisão.

Parágrafo único. O relatório mencionará o nome das partes, o pedido, a defesa e o resumo dos respectivos fundamentos."

O relatório de acordo com a disposição do parágrafo único indica quais são as partes, o pedido e os fundamentos do pedido. Esses são os três elementos que de acordo com o que jả sabemos servem para identificar a lide.

Esses elementos são necessários, pois é claro que tem a maior importância saber exatamente a que lide se refere a sentença. Ora, os elementos para identificar a lide que vai ser decidida, são: as partes, o pedido e a razão do pedido, a "causa petendi". Tudo isso deve ser mencionado pelo juiz com a máxima clareza no relatório.

Depois o juiz deve dar os fundamentos de sua decisão, fundamentos que a lei define como sendo de fato e de direito. Já sabemos que as questões que ele deve decidir são algumas questões de fato, outras, questões de direito. Esses fundamentos que o juiz deve pôr na sentença são justamente a exposição de suas observações, de seus raciocínios pelos quais ele chega à conclusão. Esses fundamentos são também chamados "motivos" da sentença.

Por que razão exige a lei que o juiz fundamente a sentença? Não será suficiente que o juiz, indicando os elementos da lide, se limite a proferir a decisão?

As razões são várias. Em primeiro lugar, a sentença não é um ato de imposição de uma vontade autoritária. E um ato de justiça, e a lei quer que o juiz procure convencer as partes da justiça de sua decisão. E não só as par- 
tes, mas também a opinião pública. O juiz deve justificar, em face das partes e em face da opinião pública, a razão pela qual decidiu de um modo ou de outro.

Em segundo lugar, a obrigação de expôr os fundamentos de sua decisão é também um modo de obrigá-lo a decidir cuidadosamente, levando em consideração todos os elementos da instrutória e todas as razões jurídicas pertinentes ao caso.

Em terceiro lugar, a exposição dos motivos da decisão é necessária para permitir o novo exame da causa no caso de haver recurso.

A terceira parte da sentença é a decisão, que se cos. tuma chamar também de dispositivo da sentença ou parte dispositiva. E parte final da sentença na qual o juiz resume brevemente e com a máxima clareza os termos de sua decisão.

A doutrina distingue entre dispositivo formulado diretamente e indiretamente. $\mathrm{O}$ dispositivo direto decide diretamente, indica com suas palavras o resultado do processo. Por exemplo, si o juiz declara: "Condeno o réu a devolver ao autor a importância que recebeu." A parte disposjtiva da sentença tem forma indireta quando, sem expressar diretamente o resultado, ou melhor imediatamente o seu resultado, se refere ao pedido do autor para declará-lo procedente ou improcedente.

Praticamente as duas formas têm a mesma consequếncia; a forma indireta, porém, é mais frequente. O juiz, em lugar de afirmar diretamente o que resolveu, se limita a declarar procedente o pedido, de modo que para se saber o resultado do processo é preciso remontar sempre ao pedido formulado pelo autor na petição inicial. Aplicando o que dissemos uma vez sobre a natureza da sentença, que ela é ao mesmo tempo um ato de inteligência e um ato de vontade, podemos dizer, aproximadamente, que os fundamentos correspondem ao ato de inteligência do juiz, e a parte dispositiva ao ato de vontade. Contudo, é importante 
não dar a essa separação das várias partes da sentença uma imporiância absoluta. Não se deve pensar que só na parte dispositiva é que se contém sempre a decisão da causa, porque os fundamentos e o relatório são necessários para interpretar exatamente o sentido da decisão. Frequentemente é nos fundamentos que se contêm alguns elementos da decisão, que não se acham depois repetidos na parte dispositiva.

Quer dizer, portanto, que a distinção entre estas várias partes da sentença deve ser entendida com um pouco de inteligência. Pode bem acontecer que nos fundamentos se encontre um ato decisório e dele devemos tomar conhecimento como se fosse contido na parte dispositiva.

\section{Os efeitos da sentença. O efeito declaratório}

Passamos agora a estudar um assunto da maior importância: os efeitos da sentença.

É claro que os efeitos da sentença podem ser vários, de acordo com a espécie de ação que foi proposta e de acordo com as várias modalidades de cada caso prático. Para estudar de forma geral estes efeitos das sentenças é preciso que procuremos algumas formas típicas dos possiveis efeitos da sentença para nelas incluir os vários efeitos que se podem produzir.

A teoria nos dá uma classificação destes efeitos da sen. tença, considerando o efeito que a sentença é destinada a produzir sobre a relação jurídica que foi objeto do processo, e deste ponto de vista os efeitos possiveis da sentença são três, e correspondem, como não podia deixar de ser, às três categorias das acões. Por conseguinte os efeitos da sentença podem ser: declaratórios, constitutivos e condenatórios.

Vamos examihar brevemente estes vários efeitos possiveis procurando evitar repetição daquilo que foi dado no ano passado a propósito da classificação das ações. Come- 
cemos pelo efeito declaratório da sentença, que consiste em estabelecer a certeza jurídica sobre a existência ou inexistência de uma relação jurídica ou excepcionalmente de um falo juridico.

$\mathrm{O}$ art. $20^{\circ}$ do Código de Processo afirma que para propôr ou contestar a ação há necessidade de legítimo interesse econômico ou moral, e o parágrafo único acrescenta: "O interesse do autor poderá limitar-se à declaração da existência ou inexistência de relação jurídica ou à declaração da autenticidade ou falsidade de documento." Neste parágrafo único encontramos a definição do efeito declaratório da sentença.

A sentença sempre, em todos os casos tem este primeiro efeito: de declarar si existe ou não a relação jurídica sobre a qual as partes controvertem, excepcionalmente, si existe ou não esse fato que é a autenticidade ou a falsidade de documentos. Normalmente a existência de simples fatos não pode ser matéria de controvérsia a ser submet:da ao julgamento dos tribunais; por isso digo que, normalmente, a declaração contida na sentença se refere à existência ou inexistência de uma relação jurídica, mas a lei excepcionalmente, permite também obter a declaração pelo juiz da existência ou inexistência da autenticidade ou falsidade de documentos, à vista das importantes consequências jurídicas que dessa declaração possam decorrer.

Ficou, portanto, provado que o efeito declaratório é constante nas sentenças. Todas elas têm esse efeito declaratório.

Pode acontecer que ele esteja sosinho; teremos nesse caso a sentença meramente declaratória. A possibilidade de uma ação tendente à obtenção de uma sentença meramente declaratória se funda neste parágrafo único do art. 2. $^{\circ}$ do Código de Processo. Na maioria dos casos, porém, o efeito declaratório se acompanha de outros efeitos, que são aqueles que iremos logo estudar: os efeitos condenatório e constitutivo. 
Efeito puramente declaratório têm todas as sentenças que declaram a improcedência da ação proposta, porque a declaração da improcedência da ação proposta pelo autor significa ao mesmo tempo declaração da inexistência da relação jurídica que o autor afirmava como fundamento da sua ação. Assim, si o autor propõe uma ação para cobrar um crédito de $\operatorname{Cr} . \$ 500,00$ e o juiz declara improcedente essa ação, qual será o efeito dessa sentença? Será um efeito puramente declaratório, isto é, a afirmação da inexistência desse crédito, da inexistência da relação jurídica creditória que o autor afirmou existir. Será uma sentença meramente declaratória, e o seu efeito pura e simplesmente declaratório.

Qual será o resultado prático conseguido pelas partes com a prolação de uma sentença que tem unicamente o efeito declaratório? Será possível, com fundamento nessa sentença, obter uma execução forçada?

Diz o art. 290:

"Na ação declaratória, a sentença que passar em julgado valerá como preceito, mas a execução do que houver sido declarado somente poderá promover-se em virtude de sentença condenatória."

Portanto, sentença que tem efeito puramente declaratório não pode dar lugar a execução alguma, mais do que isso, a definição do efeito declaratório é justamente a de não poder a sentença que tem este efeito conseguir nenhuma forma de execução forçada. O efeito declaratório consiste em declarar a inexistência ou existência dessa relação jurídica controvertida para dar certeza sobre essa inexistência ou existência, e nada mais.

Qual será o sentido desta frase contida no art. 290: a sentença que passar em julgado valerá como preceito?

Essa frase pode dar lugar à dúvida, mas posta em relação a todo o artigo, em relação ao conceito mesmo de 
ação com sentença declaratória, devemos dizer que a sentença declaratória tem um efeito puramente normativo, isto é, indica exatamente qual é a situação jurídica entre as partes, sem introduzir nessa situação jurídica nenhuma modificação a não ser a de produzir a certeza. Depoí … sentença sabemos exatamente quais são os direitos e os deveres existentes entre as partes, direitos e deveres, porém, que já existiam antes de ser prolatada a sentença, antes da propositura da ação.

Por definição, o efeito declaratório que têm todas as sentenças, seja como único efeito, seja como um dos seus efeitos, se limita a esclarecer, a declarar, por assim dizer, a pôr a limpo a situação jurídica existente entre as partes sem modificá-la de nenhum modo, declarando a situação preexistente, eliminando todas as dúvidas a respeito da existência, modalidades, ou inexistências de uma relação juridica, ou excepcionalmente de um fato jurídico.

Si a relação jurídica declarada é tal, que dela nasce um direito a obter uma prestação de outra pessoa, para poder fazer a execução forçada e conseguir a satisfação desse direito, a sentença declaratória não é suficiente, de acordo com o disposto no art. 290. Essa sentença só pode ser utilizada como fundamento de uma nova ação, para a prolação de uma nova sentença, a qual terá efeitos condenatórios, e só essa sentença permitirá fazer a execução forçada.

Essa limitação das consequências práticas no efeito declaratório não deve levar a pensar que esse efeito seja sem importância, antes, pelo contrário, pois, saber quais os nossos deveres e quais as nossas obrigações é assunto de máxima importância. Às vezes pode ser de grande interesse para o autor conhecer exatamente quais os seus direitos e quais as suas obrigações. Neste caso teremos uma ação e uma sentença meramente declaratória.

Quando o interesse do autor não se limita a esse efeito meramente declaratório, a ação que ele propõe será condenatória ou constitutiva, mas mesmo nestes casos a base 
dos efeitos ulteriores que a sentença produzirá é sempre o efeito declaratório. Este efeito declaratório é constante, está sempre presente em todas as sentenças que decidem a lide. Por vezes se encontra sosinho; por vezes constitue a base de ulteriores efeitos como vamos estudar na próxima aula.

\section{Efeito condenatório}

Começamos a examinar particularmente os efeitos da sentença. Na última aula estudamos precisamente o efeito declaratório, insistindo sobre este ponto de que todas as sentenças têm conteúdo e efeito declaratório, ao passo que os outros efeitos que pode ter uma sentença são possiveis, mas não necessários como o efeito declaratório. Quer dizer que toda sentença definitiva tem efeito declaratório. Algumas delas têm unicamente o efeito declaratório; outras, que podemos dizer a maioria, têm além do efeito declaratório outros efeitos e é justamente destes outros efeitos possiveis que vamos falar hoje. Estes outros efeitos são os seguintes: condenatório e constitutivo.

Cada um deles pode acompanhar o efeito declaratório, portanto, examinando as sentenças em geral, podemos dizer que elas ou são meramente declaratórias, quando têm só este efeito, ou são condenatórias, quando além deste efeito têm o condenatório, ou poderão ser constitutivas, quando além do efeito declaratório têm o constitutivo. Temos, pois, que examinar agora com cuidado em que consistem estes dois efeitos - condenatório e constitutivo - que podem acompanhar o efeito declaratório da sentença.

Já tivemos oportunidade de lêr o art. 290 do Código de Processo Civil. Seu texto é o seguinte:

ArT. 290 - "Na ação declaratória, a sentença que passar em julgado valerá como preceito, mas a execução do que houver sido declarado somente poderá promover-se em virtude de sentença condenatória." 
ciste artigo é suficiente para pôr em evidência qual a diferença entre efeito declaratório e condenatório. $\mathrm{O}$ efeito condenatório difere do declaratório, porque consiste em permitir a execução. Agora isto dá uma idéia geral do que é efeito condenatório, e precisamos ver como se produz este efeito.

E a decisão do juiz que tem este efeito condenatório. O juiz usa a palavra condeno, geralmente, mas o que quer dizer? A primeira idéia que vem é de que o juiz ordena ao réu de fazer alguma coisa. Esta é a opinião mais difundida entre os escritores, entretanto, não acho certa a definição de condenação como sendo uma ordem ao réu de fazer alguma coisa, isto porque a simples declaração de uma obrigação já contém a ordem da lei de cumprir esta obrigação.

Si o conteúdo da relação jurídica litigiosa é uma obrigação e o juiz declara a existência desta obrigação, disto surge para o réu imediatamente a necessidade, de acordo com a lei, de cumprir esta obrigação, não precisa de condenação. Então surgiu uma outra opinião, segundo a qual não há, na verdade, uma diferença essencial entre declaração e condenação; a diferença está no objeto. Quando o objeto é um ato ilícito então á declaração é condenação; quando o objeto é qualquer outro a declaração é simplesmente declaração, e isto, porque a simples declaração de um a $a$ o lícito traz consigo a consequência em que consiste a condenação.

Também esta opinião é errada, porque, a meu vêr, não há dúvida que o juiz, além de constatar a situação jurídica entre as partes, condena, faz em verdade duas operações - declara e condena. É algo mais que vem juntar-se à simples declaração. Que é este algo mais que vem juntarse à simples declaração?

Além dessa primeira objeção, temos em segundo lugar o artigo 290, que nos ind ca que sobre a mesma relação jurídica pode haver tanto declaração como condenação. Por exemplo, a propósito de qualquer ato ilícito que dá lugar a 
uma obrigação do réu a lei admite haver sido proposta simples ação declaratória, e dispõe que esta sentença não é suficiente para fazer a execução, isto é, precisa pleiteảr uma sentença condenatória, que contém alguma coisa a mais que a simples declaração da existência da obrigação. E essa coisa a mais é que produz o efeito característico da sentença condenatória, consistente em preparar e permitir a execução. Para entender como isso se dá é preciso considerar qual é o mecanismo da realização coativa do Direito.

o Direito é constituido de um grande número de imperativos, preceitos que ordenam as pessoas em certas circunstâncias a fazer ou não fazer alguma coisa. Si estes imperativos não forem cumpridos, há na lei, pelo seu caráter coativo, uma sanção. No Direito Privado a sanção para os imperativos da lei é a execução, portanto, condenação significa a aplicação para o caso concreto da sanção prevista pela lei, isto é, determinação, especificação da sanção.

Surge da condenação uma nova revelação jurídica de caráter processual que confere ao autor uma nova ação, a ação executória, que dá à ordem judiciária um novo poder, o de fazer execução, que impõe ao réu a necessidade de sofrer a execução forçada sobre seus bens para o cumprimento da obrigação. Chegamos, pois, à conclusão de que o efeito condenatório é, em certo sentido, efeito constitutivo.

Sabemos que o Direito se divide em material e processual. Pelo que se refere ao direito material, a condenação nada mais é que declaração, e declaração da existência de uma obrigação; mas pelo direito processual a condenação tem efeito constitutivo o qual consiste em criar uma situação que no conceito vulgar é chamada execução aparelhada, situação jurídica processual que consiste no poder do órgão judiciário de fazer a execução, no direito da parte de pedir a execução e na sujeição do réu à execução. 'Por isso a sentença que contém o efeito condenatório, e que se chama comumente sentença condenatória, tem este característico especial de constituir título executório. 
Uma sentença que declara ser improcedente uma ação condenatória, que sentença será ? É uma sentença declaratória. Declara a relação jurídica do autor inexistente.

Como saberá o juiz, em caso de achar procedente o pedido do autor, si deve pronunciar uma sentença declaratória ou condenatória? - Pelo teôr da petição inicial.

Quem escolhe si a sentença que o juiz vai pronunciar deverá ser declaratória ou condenatória? - E' o autor, que pede uma coisa ou outra.

Pode-se dizer, que o maior número de pedidos que fazem as partes é de condenação, mas não todos, porque pode haver um pedido de simples declaração. Sem dúvida, na vida diária a maior parte de pedidos das partes é condenação. Acontece que em todas as sentenças, para ser mais exato, em quasi todas as sentenças, mesmo que não sejam condenatórias há também uma condenação às custas. Já dissemos uma vez que em todo processo, qualquer que seja o objeto, há uma lide accessória, que se refere às custas do próprio processo. Já vimos no art. 283 que a sentença decidirá quanto às custas ainda que não conste da petição inicial o pedido de pagamento. Esta lide accessória tem esta especialidade de surgir independentemente de pedido, contrariamente à regra geral.

0 art. 281 do Código contém uma regra simples que não precisa especial comentário.

Art. 281 - "A condenação será em coisa ou quantia certa, podendo, todavia, ser alternativa, quando o fôr o pedido."

A condenação deve implicar na quantia da obrigação correspondente à execução, mas o parágrafo único permite que a fixação da quantia possa ficar dependendo da liquidação que será feita em procedimento especial.

Mais um assunto sobre a condenação é o seguinte: Em geral, para que se possa pedir a condenação, é preciso uma situação seguinte: a existência de uma obrigação e o não 
cumprimento desta obrigação. Este é um assunto que estudámos o ano passado, ao ver em que consistia o interesse de agir no processo condenatório. Há casos em que se pode pedir a condenação antes que finde o prazo para cumprimento da obrigação, antes que se saiba se o devedor cumprirá essa obrigação. Como?

São casos excepcionais, são aqueles em que o devedor de obrigação, de prestação periódica, não cumpriu uma ou algumas dessas prestações e há todas as razões para supor que não cumprirá as seguintes. Então a lei permite um processo todo de uma vez para pagamento da prestação vencida e das que se vencerão enquanto subsistir a obrigação.

Art. $153 \S 2 .^{\circ}$ - "Quando o pedido compreender frutos, rendas ou outras prestações periódicas, nele se incluirão, além das prestações vencidas, as que se vencerem enquanto subsistir a obrigação."

Neste caso o juiz poderá condenar para a prestação vencida e as que vão se vencer. Para estes o que ele profere é a condenação para o futuro. À medida que se vencem as prestações a sentença se torna título executório para cada uma delas.

\section{Efeito constitutivo}

Passemos a estudar o efeito constitutivo.

Qual a diferença entre efeito declaratório e constitutivo? Cría-se, modificar-se ou extingue-se a relação pelo efeito constitutivo. $O$ juiz além de declarar e constatar qual a siuação jurídica existente entre as partes pode, em alguns casos, também modificar essa situação jurídica, criando, modificando, ou extinguindo uma relação jurídica.

Vejamos um exemplo: o art. 145 do Código Civil indica os casos de nulidade de um ato jurídico: "Quando pra- 
ticado por pessoa incapaz, etc." $O$ art. 146 explica as nulidades do artigo antecedente, dizendo que podem ser alegadas por qualquer interessado, etc. Depois temos o art. 147 que indica os casos de anulabilidade por incapacidade relativa do agente, por vício resultante de êrro, dólo, coação, simulação ou fraude. 0 art. 152 explica que as nulidades do artigo 147 não têm efeito antes de julgadas por sentença.

Vemos então que pode haver ato nulo e ato anulável. Pode surgir controvérsia tanto para um como para outro. O juiz pode ser chamado a decidir esta controvérsia, mas se ê nulo o ato o juiz nada mais faz que constatar que o ato nunca existiu, tem simples aparência, e isto é o que ele declara, Si o ato é simplesmente anulável (isto quer dizer, embora viciado, tinha existência jurídica), o juiz constata a existência do vício e anula o ato.

No caso da sentença declaratória nada de novo há, sinão a certeza sobre a nulidade. Não sabiamos si era nulo ou não o ato. Na sentença constitutiva há uma coisa nova: antes existia o ato, agora não, a causa da anulação do ato é a sentença.

Para vêr bem esta espécie de efeito que a sentença pode ter, examinemos alguns casos. Vimos o do ato anulável, mas há muitos mais. A lei está cheia de casos em que a modificação não se opera "ipso jure", com o simples aparecimento dos fatos previstos pela lei; a modificação deve ser pronunciada pelo juiz. Por exemplo, artigos 209 e 212 do Código Civil sobre anulação de casamento. Nestes casos hả anulações por coação e por falta de consentimento: antes da sentença o casamento existe, é a sentença que o vai anular. Assim o desquite judicial (art. 315): é a sentença que produz este efeito característico. Interdição (art. 473). Rescisão de contrato (artigo 1092, § único). No processo temos a ação rescisória (art. 798 do Código de Processo Civil). Há casos taxativamente indicados pela lei nos quais a sentença passada em julgado pode ser rescindida; são casos de extrema gravidade. Ainda, a homo- 
logação de sentença estrangeira (art. 785). Para poder executar uma sentença estrangeira deve ela ser homologada pela autoridade judiciária no Brasil. A homologação consiste em atribuir à sentença estrangeira eficácia no interior do Brasil. E' um efeito constitutivo.

Se o autor pediu, suponhamos, sentença constitutiva e o juiz declara improcedente a ação, que sentença será essa? Declaratória.

Nas últimas aulas estudámos os efeitos da sentença, e indicámos como efeitos: o declaratório, o constitutivo e o condenatório. Conforme o conteúdo da sentença terá ela um ou mais desses efeitos, e conforme o efeito que ela produz a sentença será declaratória, constitutiva, ou condenatória. Podemos agora completar a classificação geral das decisões que fizemos no início do curso.

Classificámos as decisões em finais e interlocutórias. As finais se sub-dividem em terminativas e definitivas. As definitivas merecem estritamente o nome de sentença, e estas sentenças por sua vez se sub-dividem em: declaratórias, constitutivas e condenatórias. Assim temos o quadro completo das decisões do juiz.

Esses efeitos, de que vimos tratando ultimamente, chamam-se efeitos principais da sentença, em oposição a outros efeitos que estudaremos hoje, e que recebem o nome de efeitos secundários da sentença.

\section{Efeitos secundários da sentença *}

Não se deve crer que os efeitos secundários se chamem assim, porque sejam menos importantes que os efeitos principais. Talvez o sejam, mas o nome não é uma consequên-

(*) Cfr. o livro do autor Eficácia e autoridade da sentença, Trad. de A. Buzaid e B. Aires, Ed. da Revista Forense, Rio de Janeiro, 1945, pag. 61 e seg. 
cia de maior ou menor importància dos efeitos. 0 nome decorre do caráter accessório dos efeitos secundários, da sua falta de autonomia, no sentido que vamos explicar.

Os efeitos principais têm cada um as suas próprias condições, que o juiz deve verificar existentes no caso concreto para poder produzí-lo. Para que o juiz possa condenar o réu devem existir determinadas condições, que já estudámos convenientemente, e em consequência das quais o juiz pode condenar o réu. Sem essas condições não poderá condenar. $O$ mesmo se pode dizer para os outros efeitos principais. Cada um deles tem as suas condições particulares, peculiares.

O contrário, porém, se dá com os efeitos secundários. Eles não têm condições próprias, produzem-se por vontade expressa da lei, quando a sentença produz alguns dos efeitos principais. Eles se seguem imediatamente, automaticamente, por força da lei, porque a sentença produziu um dos efeitos principais. Consequentemente, esses efeitos secundários não constituem objeto de pedido especial da parte, nem objeto especial de pronunciamento do juiz. Nem a parte precisa pedir um destes efeitos, nem o juiz precisa expressamente declarar que ele se produza. A lei estabelece que em certos casos uma sentença, pelo fato de ser proferida, produza além do seu efeito principal, que a caracteriza, também um desses efeitos secundários. Os exemplos que daremos a seguir, de efeitos secundários, evidenciarão o caráter de falta de autonomia destes efeitos.

Efeito secundário da sentença é, por exemplo, a hipoteca judiciária, prevista no art. 284 do Código de Processo Civil:

Art. 284 - "Quando, em virtude de sentença, recair sobre os bens do condenado hipoteca judiciária, a respectiva inscrição será ordenada pelo juiz, mediante mandato, na forma da lei civil." 
A lei estabelece que a sentença condenatória produza a favor do credor de quantia certa uma hipoteca especial sobre os bens imoveis do condenado. (Hipoteca que é submetida à formalidade da inscrição para especificação - sobre bens determinados - para assegurar melhor a satisfação do débito pelo qual o réu foi condenado. Note-se, porém, que a hipoteca judiciária é uma hipoteca diferente das outras: dá ao credor o direito de sequela, não lhe dá, porém, o direito de preferência.) Essa hipoteca judiciária não é o efeito principal da sentença, é um efeito secundário. Por essa razão não é o autor que deve pedir seja constituida a hipoteca judiciária, nem é o juiz quem deve expressamente declarar na sentença que a hipoteca judiciária é constituida a favor do autor vencedor, mas o simples fato de haver uma sentença condenatória produz por força da lei esse efeito ulterior de poder o autor inscrever hipoteca judiciária sobre os bens imoveis do condenado. Não poderia o juiz condenar o réu e negar a hipoteca judiciária, assim como não poderia constituir a hipoteca judiciária e absolvê-lo. A hipoteca judiciária acompanha sempre, automaticamente, por vontade da lei o efeito condenatório, sem ter condições próprias, sem poder ser separada do seu efeito principal.

Outro exemplo: dissolução da comunhão de bens dos cônjuges por efeito da sentença que anulou o casamento ou que declara o desquite (art. 267, ns. II e III do Código Civil). O código, dispondo sobre a comunhão universal de bens no casamento, estabelece no

Art. 267 - "Dissolve-se a comunhão:

II. Pela sentença que anula o casamento. III. Pelo desquite."

Não é que o juiz ao anular o casamento também declare dissolvida a comúnhão de bens entre os cônjuges. Esse sfeito se produz imediatamente, por força de lei, como con- 
sequência da anulação de casamento. 0 mesmo se diga para o caso de desquite.

Um outro exemplo: perempção do direito de demandar em consequência de três absolvições da instância, Diz o art. 204 do Código de Processo:

Art. 204 - "Si o autor der causa a três (3) absolvições, por qualquer dos motivos previstos no artigo 201, ficará perempto o seu direito de demandar o réu sobre o mesmo objeto."

Que é absolvição da instância? E' um modo de terminar o processo sem julgamento do mérito por efeito de uma das circunstâncias indicadas no art. 201 do Código de Processo. $O$ autor pode reproduzir a sua demanda num novo processo, porém, si o faz três vezes, e deixa ocorrer uma dessas circunstâncias pelas quais há lugar a absolvição da instância, a lei considera essa atitude como vexatória e pune o autor, fazendo perimir seu direito de ação, nos termos do já citado art. 204. Não é que neste caso o juiz, além de absolver da instância o réu, declare também que está perempto o direito do autor. Ele absolve apenas o réu da instância, e por ser essa a terceira vez, automaticamente, o autor fica privado de seu direito de ação sobre o assunto, por vontade expressa da lei.

Ainda outro exemplo: o Código Civil diz no

Art. 324 - “A mulher condenada na ação de desquite perde o direito a usar o nome do marido."

Mais um exemplo encontramos no Código de Processo, no

Art. 1006 - "Condenado o devedor a emitir declaração de vontade, será esta havida por enunciada logo que a sentença de condenação passe em julgado." 
Que quer dizer "condenado a emitir declaração de vontade"? Assim como ha obrigações de dar, também ha obrigações de fazer alguma coisa, e entre estas podem existir as obrigações de declarar alguma coisa. Por exemplo: nos compromissos de compra e venda, que são o meio normal de fazer a transferência de imoveis, não há a declaração de comprar e a de vender, existe apenas o compromisso de comprar e de vender em momento sucessivo. Desse contrato surgem duas obrigações para as partes: para uma a obrigação de vender e para a outra a obrigação de comprar. Quer dizer que, quando vence o prazo, as partes estão obrigadas a emitir a declaração de vontade, que é, respectivamente, de comprar e de vender. Si uma das partes se arrepende, ou não quer mais vender, o juiz pode condenar a parte inadimplente a emitir essa declaração de vontade e como se trata de uma atitude que não pode ser substituida em forma de execução forçada, a lei admite que, condenada uma parte a emitir a declaração de vontade, a sentença mesma terá o efeito que haveria si a parte fizesse efetivamente a sua declaração.

Não é que o juiz se substitua à parte, pois que declarar a própria vontade é uma atitude que, em termos jurídicos, se pode chamar de infungível, não podendo, portanto, ser substituida por uma declaração de vontade de uma terceira pessoa; mas a lei, querendo assegurar o resultado final, estabeleceu que a sentença de condenação do réu a emitir declaração de vontade tenha os mesmos efeitos de declaração de vontade pessoalmente emitida pelo condenado. Este é um exemplo a mais de efeito secundário da sentença.

Provavelmente, percorrendo os códigos civil e comercial encontrariamos muitos outros efeitos secundários, estes, porém, são suficientes para dar uma idéia dos efeitos accessórios de alguns dos efeitos principais, estabelecidos pela lei como consequência natural, imediata e necessária da sentença pronunciada pelo juiz.

$E$ aqui terminamos o nosso estudo sobre os efeitos das sentenças, passando a examinar um assunto de importância 
relevante no nosso curso, porque constitue a teoria da coisa julgada. Preliminarmente, aviso aos srs. que o modo pelo qual vamos expor essa teoria é diferente daquele que se encontra na maioria dos livros existentes. Faz exceção, por exemplo, Baptista Martins, que nos seus "Comentários ao. Código de Processo Civil” — . $^{\circ}$ volume — preferiu percorrer o mesmo caminho nosso.

Vamos começar esse estudo com a explicação do conceito da eficácia natural da sentença. *

\section{Eficácia natural da sentença}

Eficácia é uma palavra usada em dois sentidos diferentes. Em um sentido eficácia é a aptidão de um ato de ter efeitos. Neste sentido usamos a palavra quando dizemos: "Este ato é eficaz, ou esse ato é ineficaz." $O$ ato é eficaz ou não conforme esteja certo ou não do ponto de vista da lei. Eficaz é o ato que foi praticado de acordo com o direito. Si houve algum defeito, dizemos que o ato é ineficaz.

Em um segundo sentído indicamos com a palavra eficácia o conjunto de efeitos de um ato jurídico. Usamos a palavra nesse sentido quando dizemos: "Esta sentença terá a eficácia seguinte: .." "Esta sentença tem uma eficácia muito ampla", etc.

Devemos agora examinar o conceito, o fundamento e a extensão da eficácia da sentença, que é o conceito básico da teoria da sentença e da coisa julgada.

A atividade do Estado está submetida ao direito, quer dizer, o Estado, assim como os particulares, deve conformar as suas atividades com as leis vigentes no país. Por conseguinte, só serão válidos e eficazes os atos do Estado conformes com o direito, emitidos na observância do direito vigente. Os atos legislativos, por exemplo, só são legais, só

(*) V. para o que segue o livro ido autor Eficácia e autoridade da sentença, citado. 
são válidos quando estiverem de acordo com a lei fundamental que regula a atividade legislativa, que é a Constituição. Por isso a lei vale enquanto fôr constitucional.

O mesmo se deve dizer dos atos administrativos. Eles só são válidos e eficazes quando emitidos na plena observância do direito vigente.

Idêntica afirmação se faça em relação aos atos jurisdicionais, terceira categoria dos atos do Estado. Também os atos jurisdicionais são válidos e eficazes enquanto proferidos com a observância das leis que os regulam. Uma sentença que o contrarie, ou que viole o direito que rege a atividade jurisdicional será uma sentença ineficaz, e no momento não podemos definir em que sentido esse defeito afeta as consequências desse ato.

Mas si em cada oportunidade que tivessemos de fazer uso de um ato do Estado fosse necessário demonstrar a sua conformidade com a lei, seria praticamente muito longo e muito difícil esse processo de demonstração, sempre renovado, da conformidade do ato com o direito vigente. No caso das sentenças, por exemplo, para provar que ela foi emitida de acordo com a lei, que ela é portanto válida e substancialmente justa, seria necessário renovar a cada instante o processo int'eiro que foi necessário para o seu pronunciamento, e isso seria um grave inconveniente na vida prática.

Por isso o direito, querendo afastar essa dificuldade, estabeleceu um princípio fundamental que rege toda a atividade jurídica do Estado, princípio da presunção geral de que os atos emitidos pelos órgãos estatais, tanto os legislativos como os administrativos e os jurisdicionais, estão de acordo com o direito vigente. É uma presunção não absoluta, mas existe como tal e, portanto, quem afirmar que é válido e eficaz um ato do Estado não tem a obrigação, nem o onus de demonstrar a sua conformidade com o direito, mas simplesmente deve demonstrar a existência do ato. Quem contesta a validade, a eficácia é que deverá 
provar a ilegalidade, a injustiça do ato para poder evitar os seus efeitos.

Essa é a regra geral. Uma lei vale até que se demonstre nas formas devidas ser inconstitucional. Um ato administrativo ou jurisdicional é válido enquanto não for provada a sua ilegalidade. A sentença que é tambem amparada por esse princípio fundamental da presunção da legalidade dos atos estatais, ela é eficaz em todos os sentídos até o momento em que se demonstrar a sua invalidade ou injustiça, e quem afirma essa ilegalidade é que deve demonstrar nas formas e meios devidos. A este conceito de eficácia damos o nome de eficácia natural da sentença.

Si a organização judiciária estabelecesse uma única instância para o julgamento dos processos esta eficácia começaria a existir desde o momento em que a sentença fosse proferida. Mas não é assim, porque a organização judiciária estabelece uma pluralidade de instâncias, porque permite a interposição de recursos para o controle, a revisão dos julgamentos, e surge daí o problema de saber qual o momento em que começa a existir a eficácia da sentença, assunto da nossa próxima lição.

No fim da última aula começámos a determinar o conceito da eficácia natural da sentença, que é propriamente o conjunto dos efeitos que a sentença produz como decisão final da controvérsia. Cada sentença produz os efeitos correspondentes ao seu conteúdo, podendo, portanto, tais efeitor ser condenatórios, declaratórios, ou constitutivos.

Em relação aos efeitos secundários podem existir ou não conforme o conteúdo próprio de cada sentença.

Mas em conjunto todos estes efeitos representam a eficácia natural da sentença, e essa eficácia se produz como eficácia de ato estatal, com os mesmos caracteres que apresenta a eficácia de qualquer outro ato do Estado, eficácia que está sempre condicionada à legalidade e à justiça do 
ato mesmo. Quer dizer, a sentença, assim como todos os: outros atos do Estado, produz a sua eficácia por ser emanaida por uma autoridade do Estado, mas a atividade dos órgãos do Estado está regulamentada pelas leis e seus atos produzem efeitos só se foram observados e exatamente aplicadas as leis vigentes. Em consequência, a eficácia, que a sentença produz, pode ser em cada caso eliminada, destruida si fôr possível demonstrar que o juiz errou na aplicação do direito no caso concreto.

Examinemos um pouco mais de perto essa eficácia natural da sentença: seus limites objetivos e subjetivos e o. momento em que os seus efeitos começam a ser produzidos.

Pelo que respeita aos limites é evidente que a sentença não pode ter senão eficácia para o caso concreto, para 0 . objeto próprio do processo. Só o objeto do processo foi matéria de decisão, e a decisão só pode ter efeito relativamente à matéria que foi objeto do processo. Outros. assuntos, outras controvérsias que não foram objeto do processo não podem receber de nenhum modo a eficácia da sèntença. Isto é evidente.

Quanto à extensão subjetiva da eficácia da sentença, isto é, quanto a saber quais são as pessoas que sentem a eficácia da sentença, que estão obrigadas a reconhecer os. resultados que a sentença produz, a resposta é a seguinte: a eficácia da sentença tem uma extensão geral; todos estão subordinados à eficácia da decisão. $E^{\prime}$ o juiz o órgão qủe o Estado institue para que examine e decida as controvérsias que lhe são submetidas. Em sua atividade ele deve observar todas as leis que têm a finalidade de assegurar um bom desenvolvimento dessa atividade e alcançar um resultado conforme ao direito positivo.

Todos, portanto, devem reconhecer esse resultado como manifestação da vontade do Estado na controvérsia que foi objeto do seu exame. Por exemplo: entre Fulano e Sicrano houve uma controvérsi qualquer. O juiz decidiu, declarando existente uma relação jurídica entre ambos (sentença declaratória), ou condenando o réu a pagar uma importância. 
ao autor (sentença condenatória), ou ainda anulando, modificando um contrato existente entre Fulano e Sicrano (sentença constitutiva). Qualquer destes resultados não vale só para Fulano e Sicrano, mas para todos nos limites da decisão, isto é, essa decisão é válida para todos. Todos devem reconhecer que o órgão instituido pelo Estado para resolver a controvérsia decidiu dessa maneira.

Esse o significado da nossa afirmação "a extensão subjetiva da eficácia da sentença é geral, todos devem reconhecer essa sentença nos limites do que ficou decidido." Sempre, porém, enquanto eficácia natural da sentença, isto é, enquanto eficácia subordinada e condicionada à exata aplicação do direito, porque os atos do Estado só valem enquanto contêm e representam a exata aplicação do direito vigente.

Uma sentença não tem essa eficácia imediatamente ao ser proferida. Para assegurar uma justiça melhor o Estado, não satisfeito com o simples exame feito uma só vez, por um juiz, da controvérsia a ser decidida, prevê a possibilidade de um novo exame da controvérsia, de um controle à atividade do juiz, e isso por meio dos recursos. Portanto, a sentença que profere o juiz que examina pela primeira vez uma controvérsia, ainda não é a decisão que o Estado reconhece como a sua definitiva palavra no assunto. Poderá haver um novo exame, um controle, e isso não apenas uma vez, mas mais de uma vez. Assim é pela razão de que existe um sistema de recursos, assunto muito amplo e que não é matéria de consideração no momento, mas que devemos ter presente para entender como chegamos à configuração da decisão de última instância.

Entre os vários recursos previstos pela lei há alguns que têm ef eito suspensivo, outros que não têm ef eito suspensivo. Ter ou não ef eito suspensivo significa suspender ou não o momento em que a sentença vai produzir a sua eficácia natural. Quer dizer, enquanto são possiveis os recursos com efeito suspensivo a sentença não produz efeito algum. 
Só quando se precludem os recursos com efeito suspensivo é que a sentença começa a produzir os seus efeitos normais. Podemos, portanto, afirmar o seguinte: a sentença começa a produzir a sua eficácia natural quando estão preclusos os recursos que têm ef eito suspensivo, ainda mesmo que possa ser recorrida por aqueles recursos que não têm efeito suspensivo - a revista e o recurso extraordinário.

Pela aplicação conjunta dos arts. $808, \S 1 .^{\circ}, 829$ e 830 do Código de Processo Civil podemos dividir os recursos previstos pela lei em duas categorias: os que têm efeito suspensivo e os que não o têm, que certa doutrina chama de recursos ordinários e extraordinários à vista justamente dessa diferença de terem ou não ef eito suspensivo.

Portanto, uma vez preclusos os recursos com efeito suspensivo, também chamados recursos ordinários, seja por ter decorrido o prazo para sua propositura, seja porque, propostos e recebidos foram julgados, uma vez preclusos os recursos ordinários, a sentença produz a sua eficácia natural. Eficácia que toma caso por caso o conteúdo concreto que corresponde ao caráter da decisão que o juiz proferir, mas que está sempre condicionada à verificação no caso concreto de que foi exatamente aplicada a lei vigente. Podemos apenas acrescentar, como figura excepcional, que o ef eito condenatório pode ser antecipado no que se chama execução provisória, quando o recurso, embora por sua natureza tenha efeito suspensivo, fôr recebido sem esse efeito.

Todos estes assuntos serão melhor explicados ao estudarmos o sistema dos recursos de que aquí resumidamente estou dando algumas noções para que os srs. compreendam a relação que tem o problema dos recursos com o conceito da eficácia natural das sentenças.

Temos assim diante de nós a sentença produzindo os seus efeitos do mesmo modo que produzem os seus efeitos os atos praticados pelo Estado, isto é, sempre condicionada à eficácia, à conformidade da decisão com o direito vigente. 


\section{$\mathrm{V}-\mathrm{A}$ coisa julgada}

Acontece, porém, e aquí vamos dar um passo para frente, que a lei reconhece na sentença uma eficácia maior e especial, que distingue a própria sentença de todos os outros atos do Estado. Tendo em vista a necessidade de evitar que as controvérsias possam sempre ser renovadas sem que haja um fim que venha pôr termo de uma vez aos litígios, a lei estabelece para a sentença uma qualidade especial que reforça a sua eficácia, qualidade especial característica exclusiva das sentenças e que as distingue de todos os demais atos do Estado.

Essa qualidade é o que se chama de autoridade da coissa julgada. Quando todos os recursos estão preclusos, quando não há meio algum para ser aplicado no sentido de obter uma reforma da sentença, este ato final do processo se torna imutável, inatacável. Temos então a coisa julgada formal, que significa a imutabilidade da sentença como efeito da preclusão de todos os recursos previstos pela lei. E como consequência dessa coisa julgada formal temos também a imutabilidade dos efeitos que a sentença produz - coisa julgada substancial. Enquanto a eficácia natural da sentença é como a eficácia de todos os outros atos, condicionada à verificação da justiça e da legalidade da decisão, caso por caso, quando chegamos a esse último estádio - a formação da coisa julgada - o ato se torna imutável, isto é, já não mais é condicionado à justiça e à legalidade do processo e da decisão, e a controvérsia se acha julgada definitivamente.

Embora a finalidade máxima do processo seja atingir a verdade, proclamar e realizar a justiça, o Estado se encontra na necessidade de pôr um limite a essa procura da verdade e da justiça. A lei é que proporciona aos interessados os meios que acha melhor para conseguir esse resultado. 0 juiz procede de acordo com essas regras, observando esse conjunto de garantias que a lei estabeleceu. 
Há, porém, sempre um momento em que não se pode mais discutir, há um momento em que de vez devemos estar satisfeitos com o que foi feito e reconhecer a decisão do juiz como última palavra na controvérsia decidida. Quer dizer que nem eventuais defeitos no decorrer do processo, nem êrros do juiz na decisão do caso podem mais influir para permitir que a sentença seja anulada, eliminada ou reformada. Quando chegarmos a esse momento em que recursos não mais podem ser propostos, o ato se torna imutável e em consequência disso seus efeitos também se tornam imutáveis. Alcançamos o ponto final do processo: formase a coisa julgada, e não mais se pode discutir sobre o assunto. Querendo, portanto, resumir o que foi dito e dar uma noção da coisa julgada diremos que ela consiste na imutabilidade da sentença como ato - coisa julgada formal - e na imutabilidade dos efeitos que a sentença produz, que é propriamente a coisa julgada substancial ou autoridade da coisa julgada.

Contudo, ao falar de imutabilidade da sentença e definiiividade da decisão usei sempre de uma linguagem um pouco retórica, porque o direito positivo, ao mesmo tempo em que estabelece essas regras, admite casos excepcionais em que mesmo a coisa julgada pode ser impugnada. Assim pois, em regra, qualquer defeito no processo, qualquer êrro do juiz na decisão do caso concreto depois de formada a coisa julgada se tornam irrelevantes e não podem mais ser invocados e apontados para anular ou reformar tal decisão. Mas isto só em regra, como princípio, porque a lei considera que há defeitos de tanta gravidade que não podem subsistir, e então aparece a possibilidade de impugnar a própria coisa julgada. São os defeitos previstos no artigo n. 798 do Código de Processo e que dão lugar à ação rescisória.

A ação rescisória é o último remédio que a lei prevê para impugnar a coisa julgada depois de formada. Não é um recurso, em sentido restrito, por isso que a possibilidade de propôr a ação recisória não impede a formação da 
coisa julgada; é um remédio extremo que a lei prevê e permite taxativamente nos casos relacionados no artigo citado para impedir que, quando ocorrem defeitos substancialmente graves, se torne a decisão da controvérsia definitiva.

Não será assunto a ser estudado hoje o da recisória, que aliás tem seu lugar no programa do curso. Só lhes lembrei o assunto para verem que mesmo depois de formada a coisa julgada pode haver defeitos tão graves no ato a ponto de permitir a lei a impugnação da sentença.

De acordo com uma doutrina, aliás muito autorizada, a distinção entre a coisa julgada formal e a coisa julgada substancial costuma ser feita como de dois fenômenos profundamente diferentes. A meu vêr, embora distintos, e devam ser considerados distintos, eles são nada mais do que dois degraus sucessivos do mesmo fenômeno. Proferido o ato que é a sentença, decorridos os prazos para os recursos, torna-se imutável o ato (1. ${ }^{\circ}$ degráu - coisa julgada formal), e em consequência se tornam imutaveis os seus efeitos $\left(2 .^{\circ}\right.$ degráu - coisa julgada substancial). Não há possibilidade de contrapor estes dois aspectos de um mesmo fenômeno, que é o tornar-se definitivo o ato em que o juiz proferiu a sua decisão.

Por outro lado, é interessante lembrar que há uma corrente na doutrina que considera a coisa julgada como finalidade do processo, De acordo com essa opinião a atividade jurisdicional do Estado teria como finalidade principal manter a paz entre os cidadãos; portanto, conseguir uma decisão última, definitiva, inatacável de uma controvérsia seria propriamente alcançar o escopo principal da atividade judiciária.

A meu vêr essa conceituação não é aceitável. A verdadeira finalidade da atividade judiciária é conseguir a Justiça, a aplicação e a realização do Direito em todos os casos em que ele não foi expontaneamente observado. A coisa julgada, portanto, não é a finalidade do processo, e sim um limite à procura indefinida da verdadeira finalidade do processo, que é a Justiça. 
Pelas necessidades práticas da vida, que seriam gravemente ameaçadas si essa nobre e elevada aspiração que é assegurar a Justiça não fosse limitada, é que a lei em dado momento se declara satisfeita com o que foi feito e obriga também os interessados a considerar como palavra última e definitiva do Estado o que o juiz proclamou. Mas impedir nesse momento uma continuação da discussão é pôr um limite por necessidades práticas à contínua investigação da Verdade, à procura indefinida da Justiça no caso concreto. A coisa julgada não se pode, pois, considerar o escopo do processo, mas tão somente o ponto final dele, procurando evitar a perpetuação dos litígios.

Já tive oportunidade de dizer que as definições correntes da coisa julgada são em parte diferentes da que eu dei nesta aula. Deveremos considerá-las para vêr o que há de certo ou de errado nelas.

Teorias sobre a coisa julgada

A maioria das teorias sobre a coisa julgada a define como um efeito da sentença, efeito que deve ser posto ao lado de outros efeitos da sentença, como o condenatório e constitutivo. Assim, tomando como exemplo a sentença condenatória, essas doutrinas indicam os efeitos da sentença do modo seguinte:

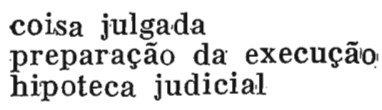

Temos, portanto, a coisa julgada posta na lista dos efeitos que a sentença condenatória produz. Isto tem a consequência de que a estabilidade, que é a característica da coisa julgada, não abrange também os outros efeitos da sentença. De fato, considerando a coisa julgada como um dos efeitos, a consequência é que os outros efeitos ficariam excluidos do âmbito da coisa julgada. 
Com a nossa definição de coisa julgada as coisas se passam diferentemente. Os efeitos da sentença condenatória seriam os seguintes:

coisa julgada $\left\{\begin{array}{l}\text { efeito declaratório } \\ \text { efeito condenatório } \\ \text { hipoteca judiciária }\end{array}\right.$ (preparação da execução)

Temos aí o conteúdo da sentença condenatória e indicámos assim os seus efeitos. A coisa julgada não é um desses efeitos, é a qualidade que reconhecemos à sentença e aos seus efeitos depois de esgotados os recursos. Não é, pois, um dos efeitos, é qualidade, que abrange todos eles, dandoIhes aquele caráter de estabilidade, de imutabilidade que já examinámos. A intenção da lei é que essa imutabilidade não se refira unicamente ao efeito declaratório, mas deve abranger todos os efeitos da sentença. Por isso é que an invés de definir a coisa julgada como efeito da sentença, poderiamos dizer que ela é uma qualidade da sentença e de seus efeitos.

Essas doutrinas passam depois a definir em que consiste este suposto efeito da sentença, que é a coisa julgada, e então usam várias fórmulas, que na sua maioria se resumem nestas palavras: presunção de verdade, ficção de verdade ou verdade legal. Todas estas definições são variações de uma afirmação feita por um jurisconsulto romano que escreveu: "Res judicata pro veritate habetur" (A coisa julgada deve ser tida por verdade). Mas ao dizer assim, o jurisconsulto romano não queria senão indicar o efeito prático da coisa julgada: o que foi julgado a lei quer que constitua o ponto final da controvérsia. Não há mais que discutir si é justa ou não a decisão. Assim foi julgado, é suficiente.

Ao transformar essa afirmação em "presunção de verdade" ou "ficção de verdade" ou "verdade legal" se diz algo parcialmente exato. Em sentido puramente científico não é exato, porque o que a lei quer não é que se finja, presumindo ser verdade o que na verdade é falso. Não se 
pode admitir que exista uma verdade legal diferente da verdade verdadeira. Todas essas fórmulas são perigosas e falsas. $O$ que a lei estabelece é que os efeitos produzidos pela sentença permaneçam no tempo, não possam ser mais modificados. E assim o faz, porque quer assegurar o fim da controvérsia, e também, porque tem bôas razões para supor que o que foi julgado corresponde a situação real existente entre as partes,

Portanto, encontramos aquí a justificação prática e política da autoridade da coisa julgada, sem que se possa concluir que destas palavras resulte a verdadeira definição jurídica da coisa julgada.

Passaremos agora a estudar o assunto de grande importância prática, discutido todos os dias nas salas dos tribunais :

\section{Limites objetivos da coisa julgada}

Essa coisa julgada que procuramos definir e explicar, a que se refere exatamente? A que parte da decisão do juiz, decisão que consta dos fundamentos de fato e de direito e do dispositivo? - Todas as partes da decisão são abrangidas pela coisa julgada, ou não?

E' o problema de saber si a coisa julgada se refere unicamente à parte dispositiva da decisão, ou si se refere também aos motivos dessa decisão.

Sabemos que o juiz não deve só decidir a causa, mas deve também dar a razão de sua decisão, os motivos que o levaram a julgar como julgou. Portanto, deve indicar quais os fatos que julgou provados, quais os dispositivos legais que considerou aplicáveis a esses fatos e qual a conclusão que tirou dessas várias premissas. A coisa julgada, isto é, a imutabilidade desse julgamento, se refere só à decisão final, ou também a todas as considerações de fato e de direito que o levaram a emitir essa decisão? Este é o problema. 
A nossa definição de coisa julgada como imutabilidade dos efeitos da sentença, já nos dá a resposta. A coisa julgada se refere aos efeitos da sentença, isto é, à decisão final, e não a todas as considerações de fato e de direito que levaram o juiz a proferir sua decisão, não, portanto, aos que se chamam "motivos" da decisão.

Dissemos em aula anterior que a decisão é um ato de inteligência e de vontade do juiz. Isto só se refere à decisão estritamente considerada. Todas as considerações que o juiz deve fazer a respeito dos fatos são atividades meramente lógica, intelectual do juiz. Ele conhece essas várias questões, mas decide unicamente a questão principal proposta pelo autor na petição inicial.

O grande mestre do processo brasileiro, PAULA BAPTISTA, já deu em seu tempo uma definição dos limites objetivos da coisa julgada, que ainda hoje é aceitável. Escreveu ele: "A autoridade da coisa julgada é restrita à parte dispositiva do julgamento e aos pontos aí decididos, e fielmente compreendidos em relação aos seus motivos objetivos." Isso significa que o conhecimento dos motivos da sentença tem a maior importância como elemento de interpretação da parte dispositiva do julgamento, mas eles próprios não são abrangidos pela coisa julgada.

Ao contrário, outra corrente tem a tendência de alargar os limites objetivos da coisa julgada, abrangendo também os motivos da decisão. JoÃo MonteIro, por exemplo, escreveu: "Fazem coisa julgada as relações jurídicas que realmente foram controversas e julgadas". Portanto, assim como vários outros autores, ele preferia extender também aos motivos os efeitos da coisa julgada. Aliás é frequentemente repetida a afirmação de que a coisa julgada se extende a todas as questões debatidas e decididas.

$O$ fato é que muitas vezes para decidir sobre a existência ou inexistência de uma relação juridica há necessidade de se examinar outras relações jurídicas mais ou menos ligadas à relação que deve ser decidida. O juiz deve examinar essas outras questões, assim como as partes de- 
vem debater essas outras relações, mas nem por isso a coisa julgada abrangerá a opinião que o juiz formou sobre essas outras relações.

A coisa julgada se limita popriamente à decisão do juiz sobre a questão proposta pelo autor em sua petição inicial. Não abrange os motivos de fato e de direito que o juiz expõe na sua decisão, ou por outra, não abrange a opinião que o juiz expressa no curso da sentença sobre relações jurídicas mais ou menos ligadas àquela que forma o objeto próprio do processo.

Essas e outras relações, para qualquer ef eito que não seja pôr novamente em discussão a relação jurídica decidida, não são cobertas pela coisa julgada, e em outros processos podem ser novamente debatidas e decididas.

Afirmamos, portanto, como conclusão do assunto, que a coisa julgada se refere estritamente àquela relação jurídica que foi objeto principal do processo, e não remonta às outras relações jurídicas eventualmente objeto de discussão, não compreende os motivos de fato e de direito da decisão.

\section{Limites subjetivos da coisa julgada}

E' assunto de grande importância prática, porque todos os dias nos encontramos na necessidade de resolver esse problema e de decidí-lo em relação às controvérsias que devem ser apreciadas pelo juiz. Tráta-se de saber quais as pessoas que são atingidas e alcançadas pela autoridade da coisa julgada.

Que o sejam as partes, não há dúvida, mas o problema é de se saber em que condição estão os outros em face da coisa julgada, porque em verdade as relações jurídicas não vivem no mundo isoladas, cada uma por si; ao contrário, se encontram continuamente entrelaçadas, ligadas. Os homens têm relações recíprocas as mais variadas e, portanto, a configuração que recebe uma relação jurídica entre $A$ e $B$ em consequência da decisão que profere o juiz pode ter certa 
influência, maior ou menor, segundo os casos, sobre as relações jurídicas de $\mathrm{C}, \mathrm{D}, \mathrm{E}, \mathrm{F}$ e assim por diante.

Até que ponto a decisão que foi proferida entre A e B vale e tem força em face desses terceiros que não foram parte no processo, que, entretanto, pela conexão que têm suas relações com aquela que foi decidida, podem receber vantagens ou prejuizos da sentença que foi proferida?

O problema é dos mais dificeis, dos mais intrincados do direito, porque, enquanto as partes tiveram oportunidade de defender as suas razões e de defender os seus interesses, os terceiros não tiveram essa oportunidade. Portanto, é da maior importância, da maior gravidade resolver o problema de se saber até onde esses terceiros, que nãu tiveram parte nenhuma no processo, que não puderam defender os seus direitos, podem ou não ser atingidos ou alcançados pela eficácia da sentença que foi pronunciada num processo entre outros.

A regra neste assunto é a seguinte: só as partes são alcançadas pela autoridade da coisa julgada. Os terceiros, por serem estranhos ao processo que teve lugar e à sentença que foi pronunciada, não são atingidos pela autoridade da coisa julgada, segundo a antiga regra formulada pelo jurisconsulto romano, que permaneceu firme através da longa tradição da história do Direito e que ainda hoje deve ser considerada como a regra fundamental nesta matéria: "Res inter alios judicata, aliis non prejudicare". (A coisa julgada entre as partes não pode prejudicar os terceiros).

Essa regra geral inspira-se no mais evidente bom senso, nas maiores exigências da equidade, da justiça, porque seria sumamente injusto que quem foi estranho ao processo, provavelmente nem sabendo da sua existência, pudesse em certo tempo ser alcançado com uma sentença que decidiu direta ou indiretamente sobre os seus direitos. Seria sumamente injusto tirar-lhe qualquer possibilidade de reagir contra essa sentença, de defender aqueles que eventualmente são seus direitos efetivos e realmente existentes. Portanto, pode-se afirmar que a regra dos limites subjetivos da coisa julgada, 
isto é, a limitação da autoridade da coisa julgada às partes, e só às partes do processo, é uma regra de importância fundamental, que deve ser defendida como garantia elementar dos direitos individuais de cada um.

Porém, o fato é que erraria quem pensasse que com isso o problema está resolvido. Na verdade, está longe de ser resolvido, pois é precisamente neste momento que começam as dificuldades; aí é que surgem as hipóteses duvidosas em que não se sabe até que ponto pode a regra fundamental ser aplicada, porque a realidade nos apresenta relações tão intimas entre os direitos, entre as relações juridicas das várias pessoas, que em certos casos é impossivel negar alguma forma de repercussão da decisão proferida em face das relações jurídicas de pessoas que foram estranhas ao processo. Portanto, em todo o tempo, desde o Direito Romano até os nossos dias, os juristas se viram na necessidade de estudar e solucionar este problema.

A regra dos limites subjetivos é a base, mas não é a solução. A configuração dos vários casos é tão diferente na prática, a realidade é tão rica de hipóteses variadas, de conexão, ligação e dependência entre uma e outra relação, que estabelecer regras completas e definitivas que resolvam todos os casos se demonstrou até agora impossivel. Em face da variedade dos casos tudo que soube fazer a doutrina foi em geral uma longa, complicada e variada casuística, solução essa evidentemente iimperfeita, porque depende das preferências, das tendências de cada um incluir ou excluir os vários casos concretos que se apresentam numa solução ou na outra.

Uma teoria recente que acreditou ter resolvido o secular problema é a teoria dos efeitos reflexos da coisa julgada. Hoje, porém, se descobriu que essa teoria a par das muitas outras anteriores ou é imperfeita, como veremos, ou se torna errada e perigosa nas suas aplicações. Essa teoria partiu de uma observação interessante do grande e conhecido jurista alemão Ihering. 
Foi ele quem primeiro observou que os atos juridicos, além de produzir os efeitos diretos, isto é, os efeitos queridos e previstosi pelo autor do ato, na realidade, produzem também outros efeitos não previstos e não queridos, mas inevitaveis, pela conexão que existe no mundo jurídico entre as várias relações. Uma pessoa age de certo modo, realiza um ato jurídico com a finalidade de produzir um certo efeito. Este efeito se produz, mas além deste efeito fóra das suas previsões, fóra de sua direta e conciente vontade produzem-se, por repercussão, outros efeitos, que atingem eventualmente outras pessoas além das que ele queria atingir com a sua atividade.

IHering se referiu, ao fazer essa observação, ao mundo jurídico em geral, e para explicar melhor seu pensamento fez uma comparação com um fato de experiência cotidiana no mundo físico, que bem nos dá a perceber o que queria dizer. Observou ele que si jogarmos uma pedra num lago, no ponto em que a pedra cái n'água, forma-se uma série de vagas que se vão distanciando, tornando-se sempre mais amplas e menos profundas. Do mesmo modo, cada atividade humana que produz um fato jurídico, e por consequência uma série de efeitos jurídicos queridos, concientemente queridos e previstos, cria em redor desse fato uma série de repercussões no mundo jurídico, que ele chamou de reflexos dos efeitos jurídicos.

Foi assim que outros escritores de direito processual, querendo aplicar esta observação de IHERING a esse problema dos limites subjetivos da coisa julgada, disseram que a coisa julgada, além dos seus efeitos diretos, que atingem as partes, produz tambem uma série de efeitos reflexos que atingem eventualmente os terceiros. Não porque esteja na intenção do juiz, na vontade do juiz, na eficácia própria da sentença produzir estes efeitos reflexos. Ao contrário, tais efeitos são à méra consequência prática, inevitavel da conexidade exist'ente entre as muitas relações juridicas existentes.

Vejamos um exemplo para esclarecer: sabemos que uma fiança, por exemplo, depende em sua existência da existên- 
cia da obrigação principal. Si a obrigação principal não existe, ou porque não surgiu, ou porque é nula, também a fiança não existe. Portanto toda controvérsia entre credor e devedor sobre a existência e validade da obrigação principal tem logicamente certa repercussão sobre a obrigação do fiador. Si o juiz declarar inexistente ou nula a obrigação principal, não poderá, "ipso jure", subsistir a obrigação do fiador, ao passo que si a obrigação principal fôr declarada existente e válida a obrigação do fiador se torna possível; não necessariamente existente, porque ela poderia ser nula por motivos próprios, mas torna-se possível. Eis como o fiador pode encontrar-șe com uma repercussão em sua relação, em sua obrigação, por força da decisão que o juiz proferir na controvérsia entre credor e devedor sobre a existência da relação jurídica principal.

A teoria dos efeitos reflexos da coisa julgada sustenta precisamente que, neste caso como em todos os outros semelhantes, a sentença produz em prejuizo dos terceiros todas. as repercussões e consequências lógicas, efeitos reflexos encerrados na sentença passada em julgado. Por exemplo: a sentença proferida sobre a existência da obrigação principal vale logicamente também para o terceiro; ele poderia eventualmente sustentar que a fiança tem algum defeito próprio, mas não poderia sustentar que a obrigação principal não existe. Como adiantei, esta teoria deve ser rejeitada.

Alguns autores prudentemente fizeram uma casuística, isto é, examinaram caso por caso se estes efeitos reflexos se podem admitir ou não, deixando-se levar por razões de equidade, mas sem poder atingir uma regra válida para todos os casos.

Outros autores, mais lógicos, criaram uma teoria de uma lógica implacável. Sustentaram que estes efeitos reflexos se produzem sempre em todos os casos de acordo com a lógica das conexões entre as relações jurídicas, e que, portanto, a coisa julgada, embora limitada nos seus efeitos diretos. unicamente às partes, produz, inevitavelmente, através dos ef eitos reflexos a sua eficácia, a sua autoridade em face dos. 
terceiros cujas relações jurídicas se encontram em alguma conexão com a relação decidida.

Essa última corrente, embora com palavras diferentes e fórmulas diferentes, chega nem mais nem menos, a negar em pleno, em todo o seu alcance o princípio geral dos limites subjetivos da coisa julgada, porque é evidente, pela natureza mesma das coisas, que uma sentença só pode produzir efeitos para os terceiros, enquanto estes efeitos decorrem da lógica aplicação da sentença sobre as relações conexas. O que admite esta doutrina é portanto o que a regra dos limites subjetivos da coisa julgada quís evitar - os efeitos reflexos da coisa julgada. É evidente que quando se diz que a coisa julgada só atinge as partes, não se quer dizer com isso que não atinge qualquer um dos muitos homens que existem no mundo e que nenhuma ligação têm com elas, porque isto não precisa ser afirmado, decorre da própria natureza das coisas. Quando dizemos que os terceiros não são atingidos pela coisa julgada, é porque queremos evitar que atinja aqueles terceiros que têm certa relação com a lide, e que poderiam, logicamente, ser alcançados pela coisa julgada, $\mathrm{E}$ por isso princípio de equidade e justiça não submeter-se à imutabilidade dos efeitos da sentença aqueles que não foram postos em condições de defender os seus direitos. Devemos, portanto, repelir como errada e sumamente perigosa a teoria dos efeitos reflexos da coisa julgada.

Ao contrário, invocamos aquí a aplicação de outra regra já exposta nas aulas anteriores e que é aquela do alcance geral da eficácia natural da sentença. Estas duas regras, limitação subjetiva da autoridade da coisa julgada e extensão geral da eficácia natural da sentença se completam entre si e nos fornecem uma solução geral do problema que estamos estudando.

Para bem entender esta solução precisamos ter presente a distinção que fizemos entre eficácia natural da sentença e autoridade da coisa julgada. A eficácia natural da 
sentença é aquela que reconhecemos à sentença pela sua qualidade de ato do Estado, portanto, condicionada à exata aplicação do direito vigente, o que em palavras mais simples significa condicionada à sua intrínseca justiça. Esta justiça, caso por caso, não precisa ser demonstrada, porque presumimos que existe, presumimos que a sentença normalmente é justa. Mas não obstante podemos demonstrar caso por caso que, na verdade, a sentença é injusta, e, portanto, sem eficácia. Como dissemos em outra parte do nosso estudo, a lei não está satisfeita simplesmente com essa eficácia natural da sentença, e para acabar as controvérsias atribue à sentença essa qualidade ulterior, que é a autoridade da coisa julgada, isto é, imutabilidade dos efeitos. Imutabilidade que é limite à possibilidade de demonstrar a injustiça da sentença. Portanto, a eficácia natural da sentença permite demonstrar caso por caso que a sentença é injusta, e, portanto, ineficaz.

Quando se verifica a autoridade da coisa julgada?

Quando a possibilidade de insurreição contra a sentença não mais existe.

Agora, eu afirmo que, enquanto a autoridade da coisa julgada se forma e existe só para as partes, a eficácia natural da sentença vale para todos. A combinação destes dois princípios nos dá a solução geral do problema que ora estudamos, o que quer dizer, em outras palavras, que, ao passo que as partes, que puderam defender os seus direitos no processo, depois de transitada a sentença em julgado, não podem mais insurgir-se contra ela para demonstrar que não é justa, os terceiros que não tiveram essa oportunidade, que não puderam defender seus direitos, são atingidos pela eficácia natural da sentença, mas podem em toda oportunidade insurgir-se contra ela para demonstrar eventualmente que no caso concreto o juiz errou e proferiu uma sentença injusta, aplicou mal a lei.

Para resolver toda a série de problemas práticos envolvidos nesta questão, devemos explicar exatamente quais os 
terceiros e em que condições podem insurgir-se contra a sentença como acabei de mencionar.

A regra sobre este assunto é a seguinte: podem se insurgir contra a eficácia da sentença os terceiros que tèm um interesse jurídico em conflito com a decisão proferida. Para entender bem este ponto examinemos alguns casos possiveis.

Entre A e B há controvérsia sobre a propriedade de um imóvel; o juiz decide a favor de $\mathrm{A}$ ou de $\mathrm{B}$, reconhecendo proprietário do imóvel A ou B. $C$, terceiro que não é parte na causa, afirma por sua vez ser proprietário do mesmo imóvel. Si a sentença entre A e B prevalecesse contra $\mathrm{C}$, pelo fato de declarar o juiz que $\mathrm{A}$ ou $\mathrm{B}$ é o proprietário, desapareceria todo o direito de $\mathrm{C}$.

Formulemos outro caso: A e B continuam contendendo sobre esse imóvel; $C$ é credor de $B$. A solução que tiver a controvérsia entre $A$ e $B$ é da maior importância para $\mathrm{C}$, porque da existência ou não do imóvel no patrimônio de $B$ pode depender a possibilidade de que $C$ seja pago.

Na hipótese primeira A e B se dizem proprietários de um mesmo imóvel, que por sua vez $\mathrm{C}$, que não é parte no processo, diz ser de sua propriedade. Si a sentença entre $A$ e $B$ prevalecesse contra $C$, produziria um prejuizo de natureza jurídica contra ele, porque negaria seu direito.

No segundo caso, reconhecendo o juiz que o imóvel é de propriedade de $A$, essa sentença prejudica $C$, porque não poderá mais fazer a execução contra $B$, seu devedor, que não dispõe de outros bens passiveis de execução e, portanto, capazes de satisfazer o crédito de C.

Embora nestes dois casos (primeiro e segundo) haja prejuizo para $\mathrm{C}$, este prejuizo é de natureza diversa: é de natureza jurídica no primeiro e de natureza econômica neste segundo, porque, negando a propriedade de $B$ sobre 0 imóvel, não se nega por isso que $\mathrm{C}$ seja credor, seu crédito subsiste intacto, só que não poderá ser satísfeito prati- 
camente, pois, o imóvel já não é mais de B. Na primeira hipótese o prejuizo é jurídico, porque importa na negação do próprio direito do terceiro, ao passo que na segunda hipótese o prejuizo é simplesmente econômico, porque a sen. tença, sem de nenhum modo afetar a existência do direito do terceiro, diminue, entretanto, as perspectivas de sua efetiva satisfação.

E' sobre essa base que, repito, podem insurgir-se contra a eficácia da sentença aqueles terceiros que sofreriam dela um prejuizo jurídico, que têm portanto um interesse juridico em conflito com a sentença proferida. Não podem insurgir-se contra ela aqueles terceiros que têm com o seu pronunciamento um prejuizo, simplesmente, prático e econômico.

As premissas que estabelecemos e cuja aplicação vai nos dar a solução dos vários casos que podem interessar são as seguintes:

1. ${ }^{\circ}$ - A sentença tem eficácia natural geral, que se extende a todos os sujeitos. Essa eficácia se torna imutável como autoridade da coisa julgada para as partes, não para os terceiros, por conseguinte os terceiros enfrentam simples: mente a eficácia natural da sentença.

$2 .^{\circ}$ - Entre os terceiros aqueles, que têm um interêsse jurídico em contradição com a sentença, podem demonstrar que ela foi injustamente proferida, e que, portanto, os seus efeitos não devem prejudicar o direito que têm esses terceiros.

Também expliquei a diferença do interêsse que pode ter o terceiro em face da sentença, interesse que pode ser jurídico, ou pode ser simplesmente prático ou econômico. $E^{\prime}$ jurídico quando há incompatibilidade entre o direito do terceiro e a decisão, isto é, quando a decisão extendida ao terceiro negaria o seu direito. Ao passo que é simplesmente interesse prático ou econômico aquele do terceiro para o qual a decisão importa em prejuizo, mas não em negação do seu direito. Exemplo clássico é o do credor do condenado. 
Vamos às aplicações. Os terceiros podem ser grupados em três categorias que chamaremos $\mathrm{A}, \mathrm{B}$ e $\mathrm{C}$.

Na primeira categoria chamada A encontramos terceiros que alcançados pela simples eficácia da sentença não podem fazer nada, mas que também não são efetivamente prejudicados por ela. São aqueles que a doutrina chama de terceiros indiferentes. Quer dizer que a sentença pronunciada entre Fulano e Beltrano faz direito entre as partes. Todos os terceiros indiferentes não têm nenhum interesse particular no assunto, não podem fazer mais que reconhecer a eficácia dessa sentença.

Uma segunda categoria, categoria $B$, é a dos terceiros que têm algum interesse no assunto, mas esse interesse é puramente prático, econômico, é um interesse de fato. A doutrina chama estes terceiros de terceiros interessados praficlamente. Para estes a decisão proferida entre Fulano e Beltrano pode representar um prejuizo, mas não podendo afirmar um interesse jurídico contra essa decisão, nada mais podem fazer que receber essa decisão e suportar as consequências eventualmente prejudiciais. Exemplo: Fulano e Beltrano litigam. Todos os credores de Beltrano estão interessados no seu processo, porque quanto maior seu patrimônio tanto maior a possibilidade destes credores de obter satisfação sobre os seus bens. Entretanto, os direitos de crédito dos credores são perfeitamente compativeis com a derrota de Beltrano no processo; grande ou pequeno o patrimônio de Beltrano, os créditos dos credores, juridicamente, ficam inalteraveis; só praticamente é que ficam afetados. Portanto, os credores de Beltrano, interessados embora no processo, porque interessados na vitória do seu devedor, no entanto, têm só um interesse prático, de fato, nada podendo fazer contra a sentença.

Quando um credor vai fazer uma execução nos bens do seu devedor, penhora um imóvel, e chega um terceiro dizendo-se e provando ser de sua propriedade esse imóvel por força de uma sentença judicial que o reconhece como proprietário, esse credor fica na impossibilidade de executar 
o imóvel, pois que não é mais da propriedade do seu devedor. As consequências práticas podem ser graves, pois, é possível que o devedor não tenha outros bens. Entretanto, que pode ele fazer? Deve reconhecer a decisão.

Os credores, assim como todos os terceiros da categoria $B$, interessados economicamente, de fato, praticamente na decisão, não podem insurgir-se contra a sentença, devem suportá-la juntamente com as consequências eventualmente prejudiciais dela decorrentes.

Um caso equivalente a esse dos credores é o caso đe todos os terceiros em face de uma decisão numa questão de estado. As questões de estado referem-se ao estado das pessoas: estado de casamento, de filiação, etc.

$E^{\prime}$ frequente a afirmação de que a coisa julgada, nas questões de estado, vale "erga omnes," contra todos. A afirmação é exata no resultado prático, mas mal formulada. Não nos encontramos em face de uma exceção ao principio dos limites subjetivos da coisa julgada, como normalmente dizem os autores, estamos simplesmente em face de um caso em que os terceiros se encontram na categoria $B$, isto é, interessados, mas com um interesse que a lei não reconhece, e portanto, devem suportar a decisão. E' só por isso, e não porque a coisa julgada tenha valor superior, pois, o "status" de uma pessoa é uma relação que por sua própria natureza deve ser igual para todos e pode influir sobre um número infinito de outras relações. Uma pessoa ou é em face do direito filho de outro, ou não é. E para todos essa afirmação ou negativa deve ser idêntica, não pode ser diferente, isto é, alguem não pode ser para uns filho de Fulano e para outros filho de Beltrano. Ou é filho de Fulano, ou é de Beltrano.

Por isso os terceiros devem ser incluidós na categoria B em face da decisão de uma questão de estado, porque a natureza particular, personalíssima das questões de estado faz com que a lei não reconheça a ninguem, senão aos próprios titulares da relação ou do estado jurídico, a legitimação para 
discutir sobre o assunto. Fulano é ou não filho de Beltrano? Quem poderá discutir este assunto? Pode haver terceiros interessados nessa solução, por muitos motivos: como credores de um deles; como sucessores de um deles. Onde vão parar os bens se o suposto filho não é reconhecido herdeiro? Eis aí consequências importantes para os terceiros. Mas o caráter personalíssimo da relação do "status" das pessoas faz com que se reconheça legitimação para discutir sobre o assunto só aos titulares da relação. $O$ interesse dos terceiros é muito inferior, de caráter subordinado, e, portanto, a lei não lhes reconhece o direito de falar sobre o assunto. Quando o juiz decide si o filho é ou não é filho, os terceiros nada mais podem fazer que reconhecer isso.

Temos ai, portanto, a categoria $B$ de terceiros interessados, mas com um interesse nitidamente subordinado ao interesse das partes no conflito, e, portanto, não autorizados a discutir a justiça da sentença proferida.

Essa é a regra, mas há também uma exceção, exceção que na verdade, devo dizer, não é prevista nem pela lei, nem pela doutrina aquí no Brasil. E' o caso da decisão fraudulenta. Está muito bem que terceiros com interesse nitidamente subordinado não possam discutir a justiça ou injustiça da sentença, como regra. Mas há uma possibilidade extrema em face da qual essa solução não satisfaz a nossa conciência jurídica, porque os titulares da relação jurídica, as partes não conduziram o processo legalmente, ha possibilidade de as partes se terem posto de acordo para prejudicar injustamente terceiros. Fulano e Beltrano se põem de acordo para conduzir o processo de tal maneira que o juiz, sem sua culpa, mas tendo por base apenas os elementos apresentados, pronuncia uma decisão não apenas injusta, mas fraudulenta. Injusta, porque produzida pelo acordo fraudulento entre as duas partes, visando prejudicar terceiros, como por exemplo os credores de Beltrano.

Neste caso para o qual o direito positivo brasileiro não prevê remédio, há em muitos direitos estrangeiros um remédio especial que se chama oposição de terceiros, remédio 
de origem francesa e que se encontra em todos os direitos influenciados pela legislação napoleônica, e que até Portugal em sua última reforma processual incluiu em seu Codigo. No Brasil, porém, não há esse remédio.

Vou por essa razão ver si é possível extrair dos principios até agora expostos um remédio para isso, porque enquanto a regra geral diz que os terceiros da categoria $B$ não devem poder discutir a decisão das partes, porque seu interesse é nitidamente subordinado ao interesse das partes no conflito, há esse caso extremo em que as duas partes se podem pôr de acôrdo para obter uma sentença injusta e fraudulenta em face de terceiros.

Em verdade, os terceiros da categoria $B$ têm um interesse que a lei, em regra, não pode reconhecer. Esse interesse torna-se, ao contrário, jurídico, digno de proteção e de consideração pela lei, quando se dirige contra uma decisão fraudulenta. Assim, um ato jurídico fraudulento pode ser impugnado pelos terceiros, art. 106 do Código Civil, pela ação pauliana. Aplicar este artigo à sentença não se pode, porque não há nenhuma analogia jurídica entre um ato de transmissão e uma sentença. Mas, e neste ponto parece que a anologia pode influir, a lei reconhece como jurídico o interesse dos terceiros em face de um ato fraudulento. E então o interesse dos terceiros da categoria $\mathrm{B}$, que normalmente não é reconhecido pela lei como hábil para discutir a decisão pronunciada, surge e se justifica uma vez provada a fraude na sentença.

Temos por último a terceira categoria, categoria $\mathrm{C}$ dos terceiros, que é a dos terceiros interessados juridicamente, e que se sub-divide em duas sub-categorias: $C=1$ e $C-2$.

Os interessados juridicamente da categoria C-1 têm um interesse igual ao interesse das partes. Por exemplo: A e B litigam sobre a propriedade de um imóvel, e apresenta-se C, dizendo-se o proprietário. $\mathrm{O}$ interesse de $\mathrm{C}$ é ígual ao de B e de A sobre o imóvel. Cada um pretende a propriedade para si, não há nenhuma diferença na qualidade do interes- 
se entre essas pessoas. Os terceiros interessados desta categoria C-1 são terceiros com interesse jurídico, com interesse que tem natureza igual ao interesse das partes no processo; portanto, a sentença pronunciada entre as partes não pode de nenhum modo diminuir o direito que ele, terceiro, tem. Para estes terceiros da categoria C-1 a sentença não representa obstáculo nenhum à plena defesa de seu direito, porque a igualdade de seu direito com o das partes têm a consequência que não há nenhuma razão para dar preferência à posição de uma parte ou do terceiro.

Vejamos um exemplo no campo das questões de estado. — Dissemos que em geral a decisão sobre questão de estado não pode ser discutida por nenhum terceiro, porque seu interesse está nitidamente subordinado ao interesse das partes. Mas pode haver o caso seguinte: A e B litigam. Diz A ser pai de B, mas vem $C$ e alega ser ele o pai de B. Ambos sustentam a mesma coisa, cada um deve poder defender as suas razões.

Por último temos a categoria C-2, categoria dos terceiros que têm um interesse jurídico, mas de categoria inferior ao interesse das partes, porque são titulares de relações jurídicas dependentes da relação jurídica julgada no processo.

Sabemos que as relações jurídicas na vida ordínária estão entrelaçadas da maneira mais vária, uma dependente da outra. A sorte que cabe a uma relação repercute de maneira variada nas outras relações mais ou menos dependentes. Os titulares destas relações dependentes estão interessados no que acontece na relação principal, mas, evidentemente, numa situação subordinada à situação dos próprios titulares da relação principal. Esses terceiros têm um interesse jurídico, porém, estão sujeitos à eficácia da sentença, sempre com a faculdade de demonstrar que ela foi proferida injustamente. Devem reconhecer a sentença, mas não a coisa julgada.

Cod. Civ. Art. 158 - “Anulado o ato, restituir-se-ão as partes ao estado, em que antes dele 
se achavam, e não sendo possivel restituí-las serão indenizadas com o equivalente."

Suponhamos que A venda a B um imóvel e B por sua vez o vende a $C$. Depois desta venda que para $A, 1 .^{\circ}$ vendedor, não tem nenhum interesse, $A$ promove uma ação contra $B$, sustentando a nulidade da venda. $O$ que acontece a $\mathrm{C}$, adquirente de boa fé? A consequência jurídica que aquí se aplica é esta: "Resoluto jure dantis, resolvitur et jus accipientis." Sendo reconhecido que nunca B comprou bem, que nunca adquiriu verdadeiramente a propriedade do imóvel, não poderia, portanto, vendê-lo a $C$, sendo, em consequência, nula a venda subsequente.

No campo do direito civil é assim, mas no direito processual dá-se o seguinte: A promove processo contra $B$, demonstrando a nulidade da venda, e quando quer fazer a execução para obter a volta do bem vem a saber que ele foi vendido a $\mathrm{C}$. Até que ponto $\mathrm{C}$, terceiro, deve reconhecer a decisão que anulou a venda, como verdadeira, como exata e justa? E' um problema muito difícil de resolver, porque de um lado seria injusto pretender que A fizesse uma segunda vez a demonstração da nulidade, depois de já ter uma sentença que reconheceu o seu direito, mas seria também injusto em relação a $\mathrm{C}$ estender-lhe a coisa julgada, porque há sempre a possibilidade de que $B$ se defendesse mal e talvez mesmo tenha havido conluio entre A e B com o intuito de lesar $\mathrm{C}$ mediante uma decisão fraudulenta. A solução que eu sustento é justa: esse terceiro, C, é atingido e alcançado pelos efeitos dessa sentença de anulação, ela vale também para ele, mas com um limite, ele poderá sempre mostrar que a sentença é injusta, que a anulação deve ser declarada improcedente, que o ato da venda deverá ser reconhecido como válido. 